\title{
Lipid composition of the cancer cell membrane
}

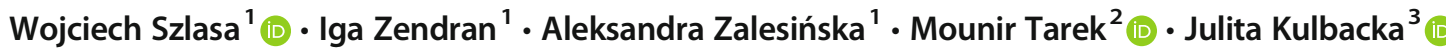

Received: 20 March 2020 / Accepted: 10 July 2020 / Published online: 26 July 2020

(C) The Author(s) 2020

\begin{abstract}
Cancer cell possesses numerous adaptations to resist the immune system response and chemotherapy. One of the most significant properties of the neoplastic cells is the altered lipid metabolism, and consequently, the abnormal cell membrane composition. Like in the case of phosphatidylcholine, these changes result in the modulation of certain enzymes and accumulation of energetic material, which could be used for a higher proliferation rate. The changes are so prominent, that some lipids, such as phosphatidylserines, could even be considered as the cancer biomarkers. Additionally, some changes of biophysical properties of cell membranes lead to the higher resistance to chemotherapy, and finally to the disturbances in signalling pathways. Namely, the increased levels of certain lipids, like for instance phosphatidylserine, lead to the attenuation of the immune system response. Also, changes in lipid saturation prevent the cells from demanding conditions of the microenvironment. Particularly interesting is the significance of cell membrane cholesterol content in the modulation of metastasis. This review paper discusses the roles of each lipid type in cancer physiology. The review combined theoretical data with clinical studies to show novel therapeutic options concerning the modulation of cell membranes in oncology.
\end{abstract}

Keywords Lipid membrane $\cdot$ Membrane composition $\cdot$ Cancer cells

\section{Introduction}

Cells in the body differ from each other to maintain the proper functioning of the tissues and organs, which they build. The lipid profile of the plasma membrane is a distinctive cell property and might be considered as characteristic for a specific cell type (Pradas 2018). Alterations arise from particular cell functions and are directly caused by increased production of various lipid components (Pradas 2018). The discussed differences include the variability of the polar head groups, as well as of the non-polar fatty acids (FA) hydrocarbon chains (Casares 2019). The head groups in the outer leaflet of the lipid bilayer can differ in simple organic compounds added to the phosphate group (choline, ethanolamine, serine). Nonpolar fatty acid moieties of the inner leaflet vary in

Julita Kulbacka

julita.kulbacka@umed.wroc.pl

1 Faculty of Medicine, Wroclaw Medical University, Wrocław, Poland

2 Université de Lorraine, CNRS, LPCT, F-54000 Nancy, France

3 Department of Molecular and Cellular Biology, Faculty of Pharmacy, Wroclaw Medical University, Wrocław, Poland hydrocarbon tail length and double bonds number or position (Rothman 1977).

The cell membrane is composed of lipids and proteins. It could either synthesise all the lipids, like hepatocytes or absorb the lipid fraction from lipoproteins circulating in the blood (Nagarajan 2019). The lipid content differs between tissues and depends on the physiological function of the cell. For instance, motile lymphocytes are characterised by low cholesterol level and high content of unsaturated lipids (Hoejholt et al., 2019). Conversely, non-motile tissues, that synthesise cholesterol are characterised by a high level of the steroid (Hoejholt et al., 2019). The lipid fraction of the plasmalemma could be divided into phosphatidic acid derivatives, glycolipids, sphingolipids and cholesterol (Fahy 2011). Phosphatidic acid could be substituted with inositol (phosphatidylinositol $\sim 4 \mathrm{~mol} \%$ of fibroblasts membrane), glycerol (phosphatidylglycerol $\sim 0.5 \mathrm{~mol} \%$ ), serine (phosphatidylserine $\sim 4 \mathrm{~mol} \%$ ), ethanolamine (phosphatidylethanolamine $\sim 8$ mol\%) and choline (phosphatidylcholine $\sim 20.25 \mathrm{~mol} \%$ ) (Fahy 2011; Hoejholt et al., 2019). Within phospholipids, the ether forms of the mentioned lipids can be distinguished, among which the most abundant are phosphatidylcholine ether $(\sim 0.25 \mathrm{~mol} \%)$ and phosphatidylethanolamine ether ( 7.75 mol\%) (Fahy 2011; Hoejholt et al., 2019). 
Glycolipids are mostly composed of ceramide or phosphatidic acid conjugated with glycan group (Yu et al. 2010). Sphingolipids are the derivatives of sphingosine attached to choline/ethanolamine - forming sphingomyelin or glycans forming cerebrosides (monosaccharide) or gangliosides (oligosaccharides) (Engelking and Engelking, 2015). Ceramide - sphingosine with fatty acid residue, is the apoptosis-inducing lipid signal (Van Blitterswijk et al. 2003). Cholesterol is the steroid compound, which content highly depends on the origin of the cell (Hoejholt et al., 2019; Pradas 2018). Namely, the motile cells, like lymphocytes are characterised by $\sim 20 \mathrm{~mol} \%$ plasma-cholesterol content and non-motile steroidogenic tissue cells by above $35 \mathrm{~mol} \%$ content (Hoejholt et al., 2019). In general, cholesterol is responsible for the cell membrane rigidity and unsaturated phospholipids for the fluidity of the cell membrane (Gracià et al., 2010; Kakorin et al. 2005). Aside from the structural role, the lipids also provide the proper microenvironment for the membrane proteins to attach (Buschiazzo et al., 2013). Proteins could be either integral part of the membrane or could be anchored by the lipid chain to the lipid bilayer (GPI) (Brown and Waneck, 1992). There might be a distinguished group of proteins that selectively accumulate in the cholesterol and sphingomyelinfull microdomains of the membranes (lipid rafts), and proteins that localise in the non-raft region (Donatello et al., 2012). The proteins are organised next to each other, allowing their direct interactions (Sezgin 2017). Membrane proteins could be responsible for physical stabilisation of the membrane, acting as the receptors or being responsible for transport across the membrane - channels and transporters (Pike 2003; Podo et al., 2016). Some proteins are also involved in signal transduction or play an enzymatic role (Lane 2015; Stellacci et al. 2009). In most cases, interactions of the lipids with cholesterol or sphingomyelin in rafts is crucial for their proper functioning, thus the destabilisation of the rafts, lead to severe clinical complications (Björkholm 2014; Weiser 2014).

Cancer cell lipid composition differs from the nonmalignant cell profile, but it also varies between malignancy types (Bernardes and Fialho, 2018; Casares 2019; Pakiet et al., 2019). Unfortunately, there is no specific lipid profile characteristic for cancer cells, that would differentiate them from nonmalignant cells (Perrotti 2016). Moreover, cancer cell lipid composition may fluctuate in time depending on its physiological condition. For instance, cells preparing for metastasis, reduce membrane cholesterol content to increase the membrane fluidity and plasticity, which is essential for penetrating blood vessels (Zalba and ten Hagen, 2017). The disorganisation of lipids in the membrane can significantly disturb cell signalling (Lladó et al., 2014). Molecular dynamics studies showed that the loss of lipid asymmetry, observed in cancer cells, leads to a decrease in their permeability (Rivel et al. 2019).

In this review paper, we present a comprehensive overview of alterations in the lipid profile of the cell membrane of cancer in correlation with its biological significance. Membrane characteristics of various malignancies, based on most recent lipidomic profiling studies are discussed as well.

\section{Membrane phospholipids}

\section{Phosphatidic acid (PA)}

Phosphatidic acid consists of diacylglycerol backbone bound to a phosphate group (Putta et al., 2016). Under physiological conditions, it accumulates on the cytoplasmic side of the plasma membrane due to the negative charge of the hydrophilic head group (Van Meer et al., 2008). Hydrophobic moieties are represented mostly by oleic, stearic and palmitic acids (Zech et al., 2009). The second binding position on the glycerol molecule is commonly occupied by an unsaturated fatty acid hydrocarbon chain (Zech et al., 2009). The content of phosphatidic acid physiologically does not exceed $1 \mathrm{~mol} \%$ of membrane lipids (Zech et al., 2009). Nevertheless, due to its negatively-charged phosphate group, phosphatic acid plays a significant physiological function. Alternations in the level of membrane phosphatidic acid are regulated by changes in its metabolism (Fig. 1). Diacylglycerol kinase (DGK) and phospholipase D (PLD) are crucial enzymes involved in PA biosynthesis pathways (Liscovitch et al., 2000; Matsubara et al., 2006). Conversely, the degradation of PA is indirectly caused by phospholipase A (PLA) (Brindley 1996, 1998). DGK is regulated in a hormonal way. The stimulation by vascular endothelial growth factor (VEGF) leads to the activation of Src protein-tyrosine kinase (c-Scr) and Abl proteintyrosine kinase (c-Abl), leading to the enhance in DGK activity (Baldanzi et al. 2008; Baldanzi et al., 2004; Matsubara et al., 2012). This promotes DGK trafficking to the plasma membrane, which eventually induces PA biosynthesis (Purow 2015). DGK may be activated by pathogen-induced enhanced phospholipase (PLC) activity as well (Stith 2015). PA biosynthesis is also catalysed by PLD which activity is G-protein-dependent (Brandenburg 2014). The G-proteins' $\beta$ and $\gamma$ subunits $(G \beta \gamma)$ function as negative regulators of PLD activity, whereas G12/ G13 proteins' $\alpha$ subunits promote the activity via several other factors, such as pyruvate kinase (Pyk), phosphoinositide-3kinase- $\gamma(\mathrm{PI} 3 \mathrm{~K}-\gamma)$, Rho guanine nucleotide-exchange factor (Rho GEF) and Rho factor (Hess et al. 1997; Lucas et al. 2002; Mariggiò et al., 2006; Preininger et al., 2006). Changes in the activity of the above-mentioned proteins are associated with carcinogenesis. Interestingly, aside from cancer, the process of PLD activation is also involved in physiological processes, such as wound healing (Arun et al. 2013).

PLA is responsible for the conversion of PA into lysophospholipid, which results in its withdrawal from the cell membrane to the cytoplasm. PLA activity highly depends on the activity of membrane hormone receptors, such as 5-HT2, 


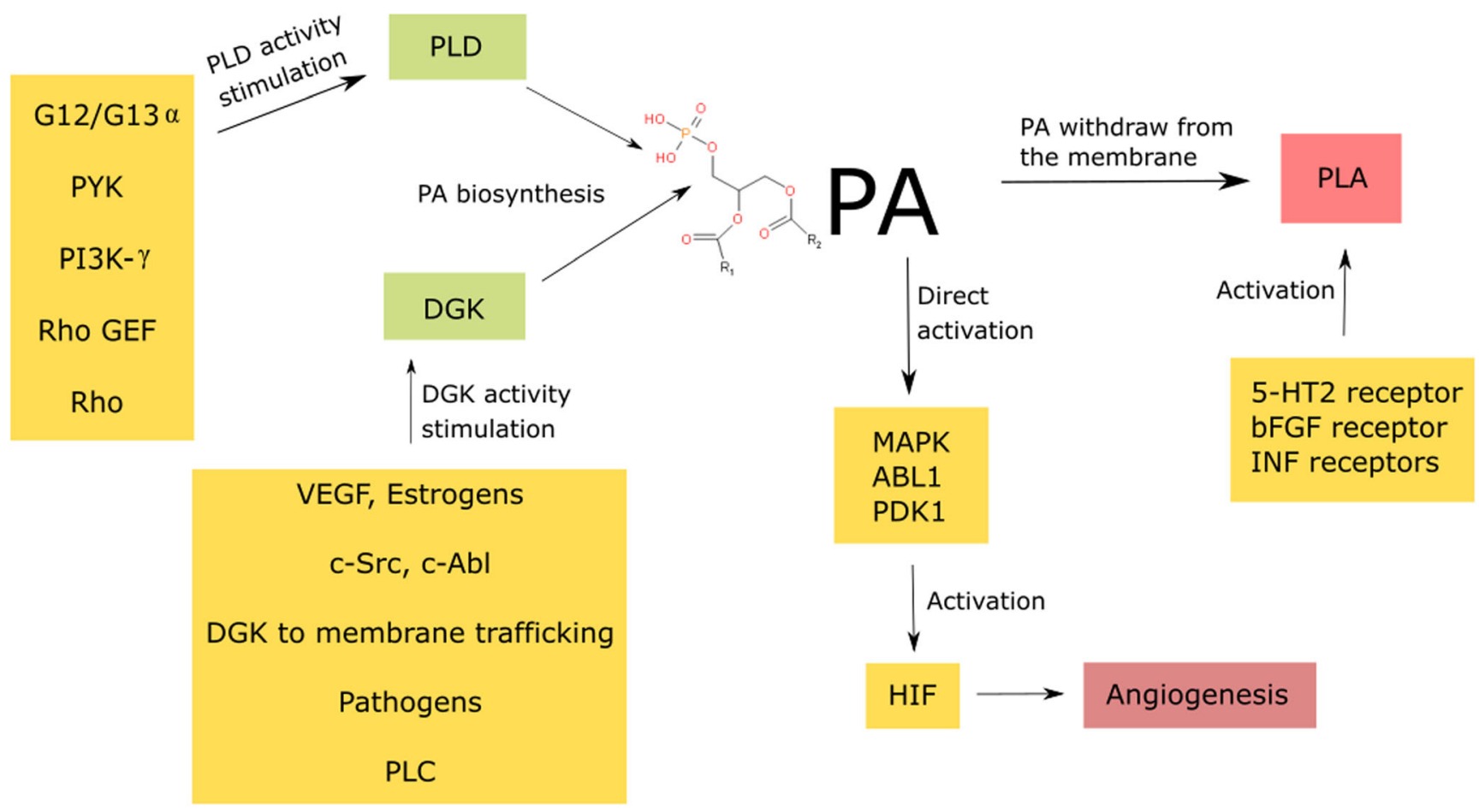

Effector molecules and factors

Biological effect

Fig. 1. Phosphatidic acid (PA) biosynthesis is being stimulated by VEGF, estrogens, c-Src and c-Abl. Pathogens, PLC and DGK trafficking towards cell membrane increase the PA biosynthesis. The lipid directly activates MAPK, ABL1 and PDK1 kinases, leading to the HIF activation and thus neovascularization. Conversely, factors stimulating PLD, like PYK, PI3K-gamma, G12/13 alpha subunits activation, Pho GEF and Rho, lead to the increased activity of PLD, which catalyzes the PA degradation; DGK - diacylglycerol kinase, PLD - phospholipase D, VEGF - vascular

bFGF and INF receptors (Goddard 1992; Kurrasch-Orbaugh 2003; Wu et al., 1994). bFGF activates PLA2 indirectly, by enhancing the release of PLA2-activating protein (Goddard 1992). With the stimulation of INF- $\alpha / \beta / \gamma$ and 5-HT2R, PLA activity increases as well (Kurrasch-Orbaugh 2003; Wu et al., 1994). Conversely, PLA2 deactivates in response to glutamine and oxidants (Huang et al., 2020; Lee 2015).

Elevated levels of PA are related to a series of changes to cancer cell metabolism. Primarily, it activates kinases, such as mitogen-activated protein kinase (MAPK), ABL tyrosine kinase 1 (ABL1) or 3-phosphoinositide-dependent protein kinase-1 (PDK1), implicated in intracellular stress signalling pathways (Lee et al. 2001; Plattner et al. 1999; Putta 2016). The aforementioned enzymes are also associated with cancer initiation and progression (Papageorgis et al. 2011; Papandreou et al. 2011; Reynaert et al. 1992). Moreover, the elevated level of PA enhances hypoxia-inducible factor 1-alpha (HIF1A) transcription which promotes angiogenesis and cancer cell proliferation (Han et al. 2014).

\section{Enzymes increasing lipid concentration}

Enzymes decreasing lipid concentration

endothelial growth factor, c-Src - Proto-oncogene tyrosine-protein kinase Src, c-Abl - Abl protein-tyrosine kinase, PLC - phospholipase C, HIF hypoxia-inducible factor, MAPK - mitogen-activated protein kinases, ABL1 - Abelson murine leukaemia viral oncogene homolog 1, PDK1 Phosphoinositide-dependent kinase-1, G12/G13 $\alpha-\alpha$ subunits of heterotrimeric G proteins, PYK - pyruvate kinase, PI3K- $\gamma$ phosphoinositide 3-kinase $\gamma$, Rho - Ras homologous protein factor, Rho GEF - Rho guanine exchanging factor;

\section{Phosphatidylinositol (PI)}

Phosphatidylinositol (PI) family is a heterogeneous group of membrane lipids that differ from each other with regard to fatty acid moieties composition and the number of phosphate groups attached to polar myoinositol head group (Yeagle 2016). Phosphoinositides are the phosphorylated forms of phosphatidylinositol (Falkenburger et al., 2010). It is possible to distinguish phosphatidylinositol mono- and bisphosphates phosphorylated on the $\mathrm{C} 3, \mathrm{C} 4$ or $\mathrm{C} 5$ positions of the inositol ring, as well as triphosphate with phosphate groups in all three of the positions (Yeagle 2016). Phosphorylation is possible due to the specific activity of phosphatidylinositol phosphate kinases (PIPK) (Muftuoglu et al. 2016; Rajala and Anderson 2010). Conversely, dephosphorylation is catalysed by specific phosphatases (Hsu and Mao, 2015).

Plasma membrane level of PI is volatile and fluctuates between 5 and $12 \mathrm{~mol} \%$ with regard to HT-29 colon cancer cell line and Jurkat cell line, respectively (Hoejholt et al., 2019; Zech 
et al., 2009). Under physiological conditions, phosphoinositides are present in the outer leaflet of the membrane (Van Meer et al., 2008). Most phosphoinositides contain stearic or oleic acid in the sn-1 carbon; arachidonic or oleic acid is bound by sn-2 carbon atom (Zech et al., 2009). However, as a result of a high diversity of the phosphoinositol family and variety of their metabolic functions, it is impossible to fully comprehend the contribution of phosphoinositides to the lipid membrane profile.

Each of the phosphoinositides exhibits specific metabolic activity and affects different cell signalling pathways. Phosphatidylinositol-3-phosphate recruits proteins involved in membrane trafficking (Nascimbeni et al., 2017). Phosphatidylinositol-4-phosphate is an important component of the membrane of the Golgi apparatus, recruiting proteins for the transport to the cell membrane (Hammond et al., 2014). Conversely, phosphatidylinositol 5-phosphate participates in proliferation control by modulating both histones acetylates and deacetylases activity, as well as p53 acetylation (Poli et al., 2019). The activity of the enzyme is performed via the inhibitor of growth 2 (ING2) (Poli et al., 2019). Curiously, phosphatidylinositol monophosphates are involved in membrane curvature regulation (Gallop et al., 2013).

Phosphatidylinositol bisphosphates (in particular phosphatidylinositol 4,5-bisphosphate) function as secondary messengers in many signalling pathways (Falkenburger et al., 2010). Besides, phosphatidylinositol 4,5-bisphosphate binds proteins responsible for actin filaments organization, as well as stabilises $G$ protein-coupled receptors, enhancing the effectiveness of various signalling pathways (C. Y. Wu et al., 2014; Yen et al., 2018). Additionally, phosphatidylinositol 4,5bisphosphate promotes the membrane recruitment of $\mathrm{G}$ protein-coupled receptor kinase 2 (GRK2) - one of the G protein effector molecules (Pitcher et al., 1996).

Phosphatidylinositol bisphosphates are not located only in the plasma membrane, but also in the endomembrane system. Phosphatidylinositol 3,5-bisphosphate may be found in the intracellular membranes, where it forms vacuole and alveoli, as well as participates in exocytosis ( $\mathrm{Li}$ et al., 2013). Therefore, the lipid is of particular importance for actively secreting cancer cells (King et al., 2012). Considering the above, cancer cell secretion could be inhibited by targeting the phosphatidylinositol 3,5-bisphosphate biosynthesis pathway (Thapa et al., 2016). Phosphatidylinositol bisphosphates are involved in ion channels regulation as well. (Mccartney et al., 2014). By affecting the potassium channels, the resting membrane potential is modulated, serving as a proliferative signal. It is frequently found in cancer cells (Yang and Brackenbury, 2013).

Phosphatidylinositol $(3,4,5)$-trisphosphate accounts for numerous cellular signalling pathways activation, i.e. protein kinase B (AKT) pathway, therefore contributing to cell growth and survival regulation (Manna and Jain, 2015). Like other phosphoinositides, phosphatidylinositol $(3,4,5)$-trisphosphate participates in the recruitment of proteins with pleckstrin homology domain (PH domain) (Milburn et al., 2003). These include a large number of proliferation-related kinases, such as AKT, PDK1 or Bruton's tyrosine kinase (BTK) (Manna and Jain, 2015).

One of the most significant functions of phosphatidylinositol phosphates is the formation of GPI-anchor, thus allowing the motile protein-membrane interactions (Brown and Waneck, 1992). Phosphatidylinositol enables attachment of freely floating proteins to the lipid bilayer of the membrane through hydrophobic interactions within the nonpolar membrane core (McLaughlin and Murray, 2005).

Phosphoinositides biosynthesis impairment is caused by specific kinase dysfunction. Contrarily, phosphatidylinositol accumulation occurs when PI specific phospholipase C (PI PLC) remains inactive or mutated (Cocco et al., 2006). $\beta$ and $\gamma$ subunits of G-protein decreases the activity of PI PLC (fig. 2) (Rhee 2001).

\section{Phosphatidylglycerol (PG)}

Phosphatidylglycerol structure consists of phosphatidic acid bound to glycerol substituent (Yeagle 2016). The lipid is an anionic intermediate of the cardiolipin biosynthesis pathway (Yeagle 2016). Although phosphatidylglycerol comprises only about $1 \mathrm{~mol} \%$ of the membrane phospholipids, it remains an important component of the cytosolic side of the plasma membrane due to its ionic properties (Zech et al., 2009). Oleic and palmitic acid moieties are the most common glycerol substituents for phosphatidylglycerol (Zech et al., 2009).

Certain studies have demonstrated that phosphatidylglycerol accounts for protein kinase $\mathrm{C}$ (PKC) activation and that it is involved in viral transcription (Bailey et al., 2017; Hirai et al., 1992; Murray and Fields, 1998). Moreover, phosphatidylglycerol participates in viral envelope formation (Sands and Lowlicht, 1976). At the tissue level, phosphatidylglycerol can inhibit phosphatidylcholine transfer between membranes, which results in membrane structure and function irregularities (Wirtz et al., 1976). The importance of this compound during viral infections may suggest that its abnormal levels could be observed in virus-associated cancers such as cervical cancer (Preetha et al., 2005). These fluctuations may lead to an increase in viral replication effectiveness and cell neoplasia (Fig. 3).

\section{Phosphatidylserine (PS)}

Phosphatidylserine under physiological $\mathrm{pH}$ is defined as negatively charged lipid, present in the intracellular layer of the cell membrane (Yeagle 2016). Its volume in the cell membrane is estimated at around $6 \mathrm{~mol} \%$ (Zech et al., 2009). Its degradation by decarboxylation merges with the biosynthesis process of phosphatidylethanolamine, which occurs in large quantities in the plasma membrane (Dawaliby et al., 2016). 


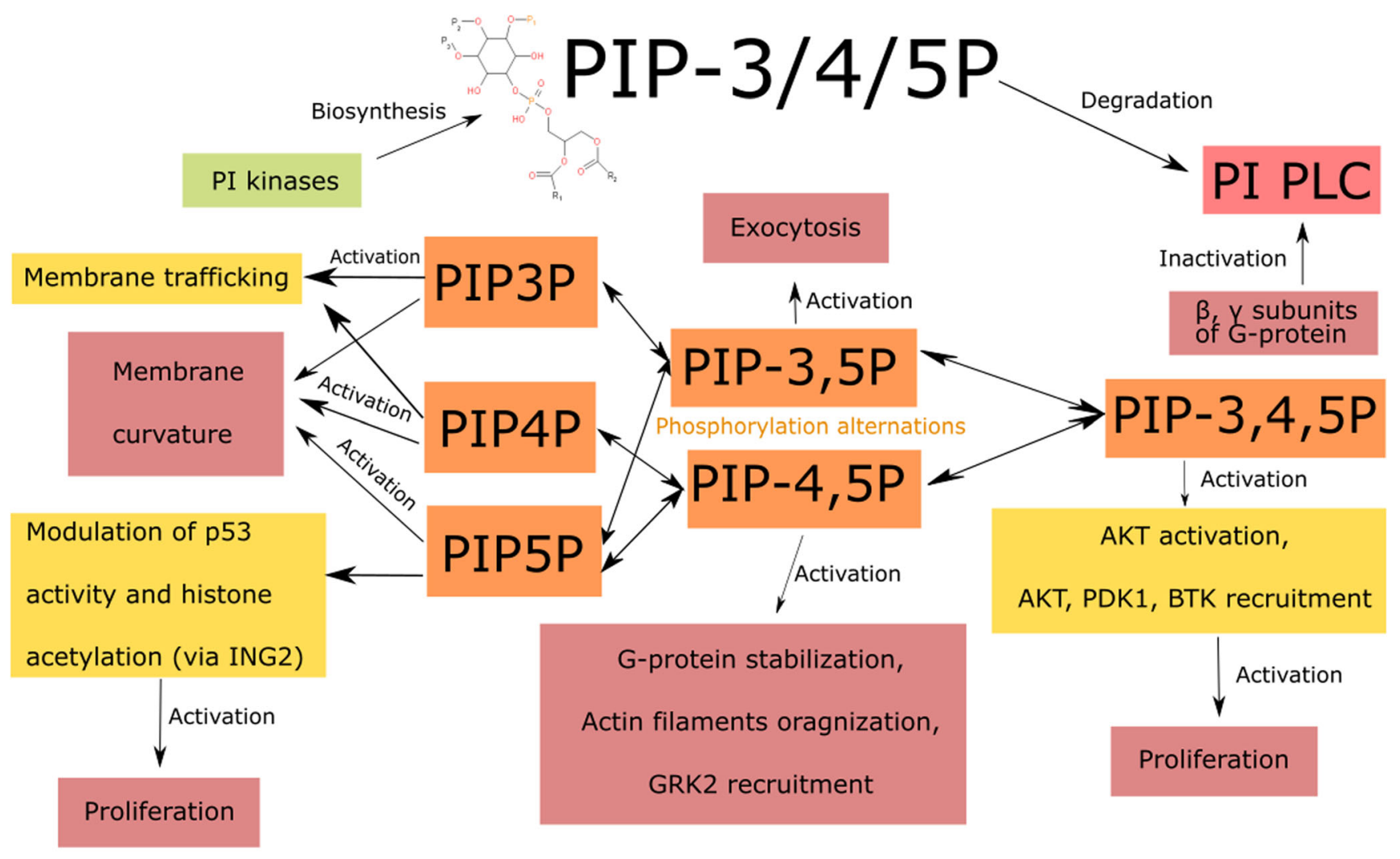

Effector molecules and factors

Biological effect

\section{Enzymes increasing lipid concentration}

Enzymes decreasing lipid concentration
Fig. 2. Phosphoinositides (PI) metabolism and action scheme. Diphorylated phosphatidylinositol forms are responsible for cancerrelated microsomes exocytosis, G-protein stabilization and constant activation, actin filaments prometastatic organization and GRK2 mediated proliferator signal transduction. Various mono-phosphorylated forms of phosphatidylinositol are responsible for membrane curvature modulation or induction of proliferation; PIP-3/4/5P - phosphatidylinositol 3/4/5-

Like PE, PS is mostly composed of palmitic, oleic and stearic acids attached at the $\mathrm{C} 1$ ' glycerol position and residues of oleic acid in C2' position (Zech et al., 2009).

The biosynthesis of phosphatidylserine is associated with the activity of two phosphatidylserine synthase isoforms (PSS I and II) (Stone and Vance, 2000). Those catalyse choline to serine substitution in phosphatidylcholine and ethanolamine to serine substitution in phosphatidylethanolamine, respectively (Arikketh et al., 2008; Kuge \& Nishijima 1997; Kuge et al., 1997). The process of phosphatidylserine degradation, however, takes place thanks to the phosphatidylserine decarboxylase which catalyzes its decomposition to phosphatidylethanolamine (Fig. 4) (Vance and Steenbergen, 2005).

The apoptosis signalling was considered to be the major cellular role of phosphatidylserine, however, nowadays, some authors prove that PS does not induce apoptotic but rather necroptotic cell death type (Shlomovitz et al., 2019). This happens when the phosphatidylserine passes to the outer layer of the phosphate, PIP-3,5P - phosphatidylinositol 3,5-diphosphate, PIP-4,5P phosphatidylinositol 4,5-diphosphate, PIP-3,4,5P - phosphatidylinositol 3,4,5-trisphosphate, ING2 - inhibitor of growth protein 2, p53 - transformation-related protein 53, AKT - protein kinase B, PDK1 - protein 3phosphoinositide-dependent protein kinase-1, BTK - Bruton's tyrosine kinase, GRK2 - G-protein-coupled receptor kinase 2; PI PLC - PI specific phospholipase $\mathrm{C}$.

cell membrane due to the activity of an enzymatic protein called calcium ion-dependent flippase (Segawa and Nagata 2015). Physiologically, during apoptosis, phosphatidylserine is exposed on the cell surface, while in cancer cells, the process is present also during cellular oxidative stress (Belzile et al., 2018). Due to this, phosphatidylserine excess may be considered as a tumour marker (Sharma and Kanwar, 2018).

Phosphatidylserine is exposed on the surface of cancer cells to avoid the autoimmune response of the organism (Birge et al., 2016). It protects the cancer microenvironment from NK cells and other cytotoxic immune cells (Lankry et al., 2013). Thus, cancer cells are no longer recognised as a threat to the immune system. Interestingly, numerous intracellular bacteria and viruses can induce similar effects, suggesting the convergent evolution of pathogens and cancers (Birge et al., 2016). Currently, an attempt is made to target phosphatidylserine excessively exposing cells in cancer therapy (Belzile et al., 2018; Budha et al., 2018). 


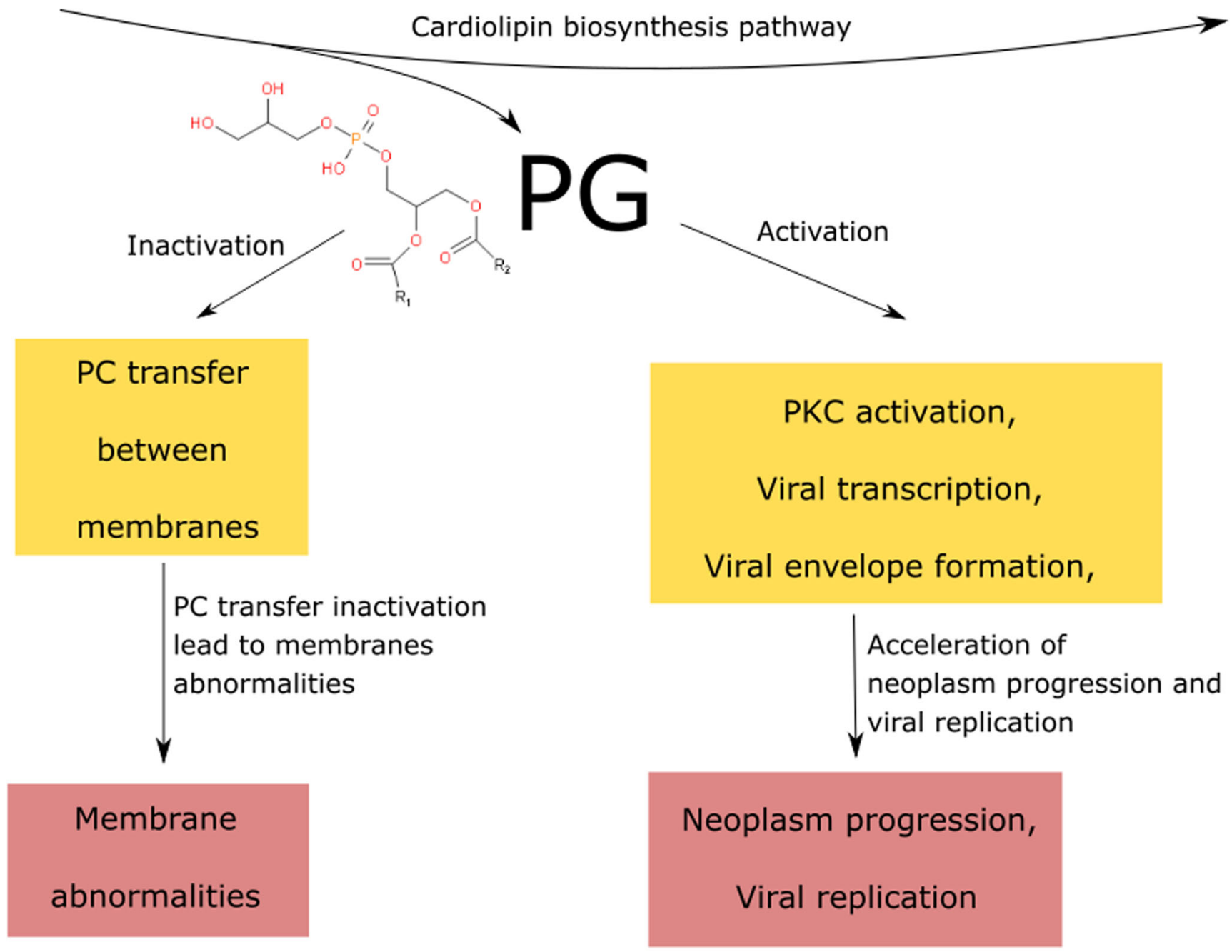

\section{Effector processes and factors}

\section{Biological effect}

Fig. 3. Phosphatidylglycerol (PG) is being synthesized as the intermediate metabolite in cardiolipin biosynthesis pathway. The lipid inhibits PC transfer between membranes, leading to the cancerous membrane abnormalities. PG activatess PKC, viral transcription and envelope formation, leading to the neoplasm progression and increased ratio of viral replication; PC - phosphatidylcholine, $\mathrm{PKC}$ - protein kinase C;

\section{Phosphatidylethanolamine (PE)}

Phosphatidylethanolamine is the second most common (15-25 mol\%) membrane phospholipid, occurring in ester or ether form (Zech et al., 2009). The ether fraction prevails over the ester fraction under physiological conditions (Zech et al., 2009). However, cells at a higher risk of disintegration of the plasma membrane tend to exhibit increased ether to ester ratio due to the greater thickness and denser packing of plasmalogens within the membranes (Rog and Koivuniemi, 2016). Due to its wedge shape, phosphatidylethanolamine is responsible for plasma membrane curvature modulation (Lladó et al., 2014). Although phosphatidylethanolamine is present on both sides of the plasma membrane, it exhibits the greatest concentration in the cytosolic leaflet of the lipid bilayer (Yeagle 2016). Interestingly, in numerous cancer cell types, phosphatidylethanolamine distribution is reversed with a preference for the outer leaflet of the plasma membrane ( $\mathrm{Liu}$ et al., 2017 a.

Chemical analysis shows that palmitic, stearic and oleic acid chains are the most common fatty acids residues in phosphatidylethanolamine structure (Zech et al., 2009). Phosphatidylethanolamine ester is a product of phosphatidylcholine demethylation by phosphatidylcholine Nmethyltransferase and phosphatidylserine decarboxylation by phosphatidylserine decarboxylase (Bleijerveld et al., 


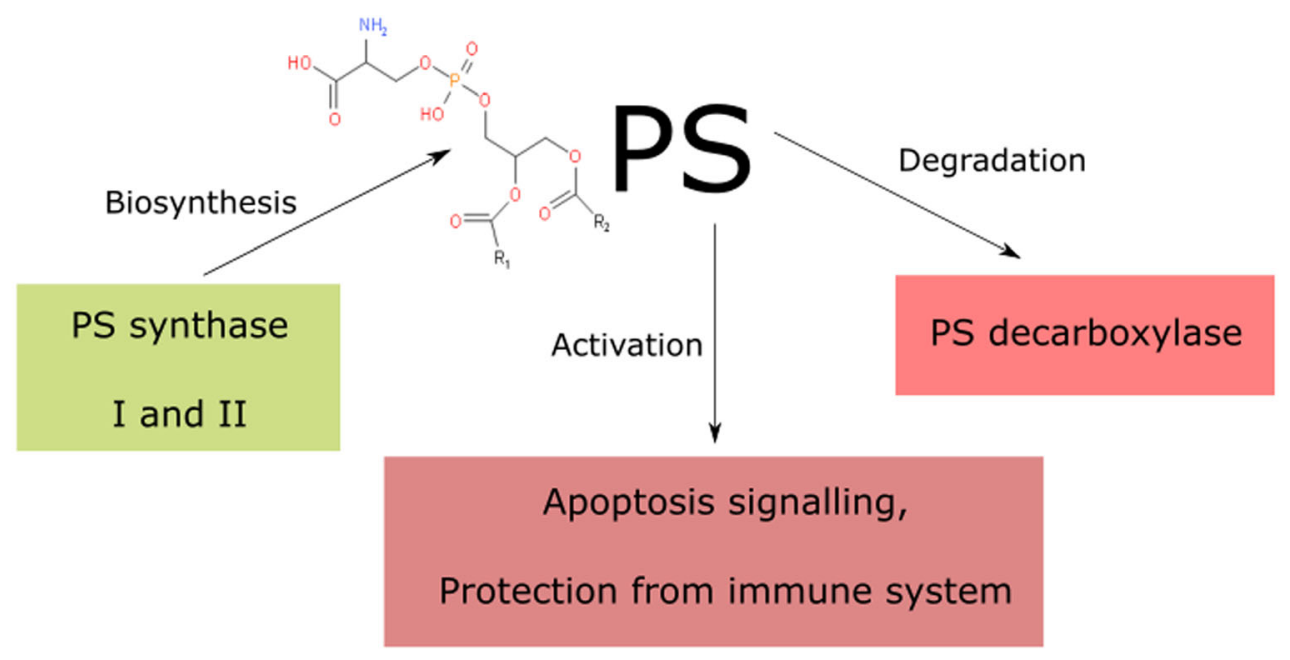

Biological effect

Enzymes increasing lipid concentration

Enzymes decreasing lipid concentration

Fig. 4. Phosphatidylserine (PS) biosynthesis is being catalyzed by PS synthase I or II. The degradation is catalyzed by PD decarboxylase. The increased PS content in the cell membrane leads to cancer cell protection from the immune response. However, the increase in PS in the outer membrane of the cell leads to the escalation of apoptosis signaling.

Phosphatidylethanolamine exerts its intracellular biological functions via the phosphatidylethanolamine-binding protein (PEBP) (Wang et al., 2004). PEBP acts as an inhibitor of serine proteases, negatively regulating the apoptotic process (Rockenfeller et al., 2015). Furthermore, increased phosphatidylethanolamine levels were observed during laboratoryinduced ER stress (Shyu et al., 2019).

As a part of the glycosylphosphatidylinositol (GPI) anchor, phosphatidylethanolamine is responsible for binding proteins to the membrane (Menon et al., 1993; Signorell et al., 2008). In this process, phosphatidylethanolamine is the donor of the phosphoethanolamine group that is attached either to the $\mathrm{C}$ terminus of the protein or to the hydroxyl groups of the glycan-core mannose (Patel and Witt, 2017). The impairment of GPI-anchor biosynthesis results in improper stabilisation of the proteins in the membrane area (Krawitz et al., 2013). Consequently, intracellular signalling pathways, biosynthesis and degradation reactions, as well as cell communication, may all be affected, leading to the cellular dysregulation and carcinogenesis (Fig. 5).

Unsaturated bonds in the hydrocarbon chains of phosphatidylethanolamine are susceptible to ROS-mediated oxidation (Iuchi et al., 2019). The process is tightly connected with ferroptosis - a type of cell death, induced by the accumulation of lipid peroxides in the membrane (Conrad et al., 2018). This results in regulated cell death, that lacks characteristic features of apoptosis, such as caspase activation (Du et al., 2020; Xu et al., 2019). Ferroptosis is thought to be the only type of the cell death from which cancer cells cannot escape, thus the researchers try to introduce it to cancer therapy (Bebber et al., 2020; Xu et al., 2019). (Beloribi-Djefaflia et al., 2016). 


\section{PC N-methyltransferase}

PS decarboxylase

Cytidine diphosphate-ethanolamine pathway

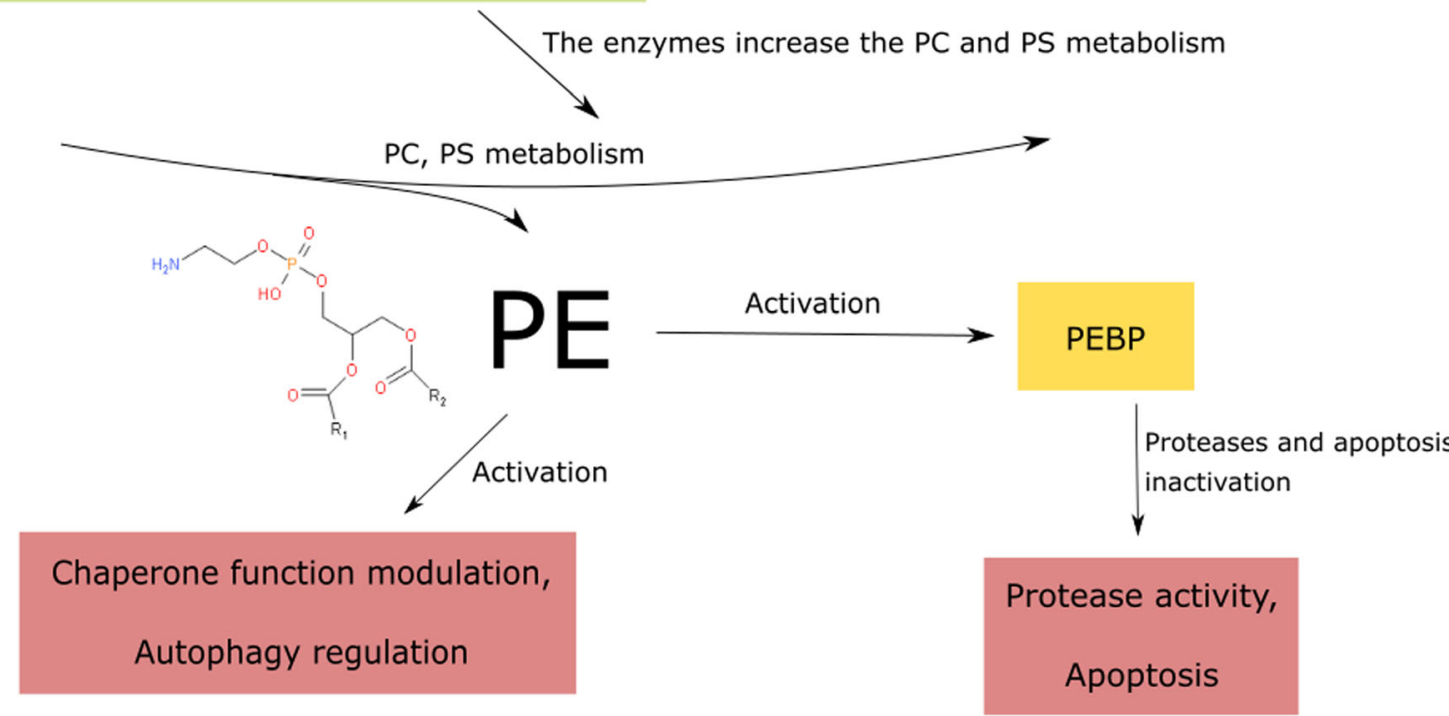

Effector molecules and factors

Biological effect

Fig. 5 Phosphatidylethanolamine (PE) is being synthesized by the induction of PC N-methyltransferase, PS decarboxylase and CDPethanolamine pathway. The increased PE content in cell membrane leads to the activation of PEBP, which desensitizes the cell from the

\section{Phosphatidylcholine (PC)}

Phosphatidylcholine is a neutral membrane lipid, present in both ester and ether forms, the same as phosphatidylglycerol (Yeagle 2016). Although phosphatidylcholine is primarily a neutral lipid, it can also be referred to as a zwitterion, as it consists of a positively charged choline head group and a negatively charged phosphate group substituent (Yeagle 2016). Phosphatidylcholine is the most abundant compound of the lipid bilayer (Zech et al., 2009). In comparison to phosphatidylethanolamine, it is mostly present in the outer leaflet of the plasma membrane and higher ester/ether form ratio (Zech et al., 2009).

Considering common biosynthesis pathways, fatty acid residues of phosphatidylcholine are similar to those of phosphatidylethanolamine and phosphatidylserine (Yeagle 2016). Phosphatidylcholine is biosynthesised in the Kennedy pathway or phosphatidylethanolamine Nmethyltransferase pathway (Gibellini and Smith, 2010). Impairment of phosphatidylcholine biosynthesis causes its membrane level to decrease simultaneously with an increase in phosphatidylethanolamine accumulation.
Enzymes and metabolic pathways increasing lipid concentration

proapoptotic signals. Conversely, PE directly modulates the chaperone functions of the membrane-associated proteins. PC - phosphatidylcholine, PS - phosphatidylserine, PEBP - phosphatidylethanolamine binding protein.

A wide range of cancers exhibits phosphatidylcholine metabolism alterations, caused mainly by choline kinase alpha (CHKA), phospholipase C (PLC) or phospholipase D (PLD) enhanced activity (Hu et al., 2016). CHKA is responsible for the increase in phosphorylated choline level, serving as a substrate for cytidine diphosphate (CDP)-choline phosphocholine transferase in the CDP-choline pathway (Arlauckas et al., 2016; Sola-Leyva et al., 2019). Conversely, PLC catalyses the degradation of phosphatidylcholine with the release of diacylglycerol (DAG), promoting cellular anabolism via protein kinase A (PKA) (Oude Weernink et al. 2007; Siso-Nadal et al., 2009). These metabolic shifts lead to the accumulation of energy-rich molecules, providing sources for cell proliferation. Carcinomas, such as breast cancer overexpress the above-mentioned enzymes (Fig. 6) (Podo et al., 2016).

\section{Lysophosphatidylcholine and lysophosphatidylethanolamine}

Lysophospholipids are phospholipids without an acyl chain at the $\mathrm{C} 2$ carbon position. Although lysophospholipids are nearly detectable in the plasma membrane, the lipids are involved 
Kennedy pathway,
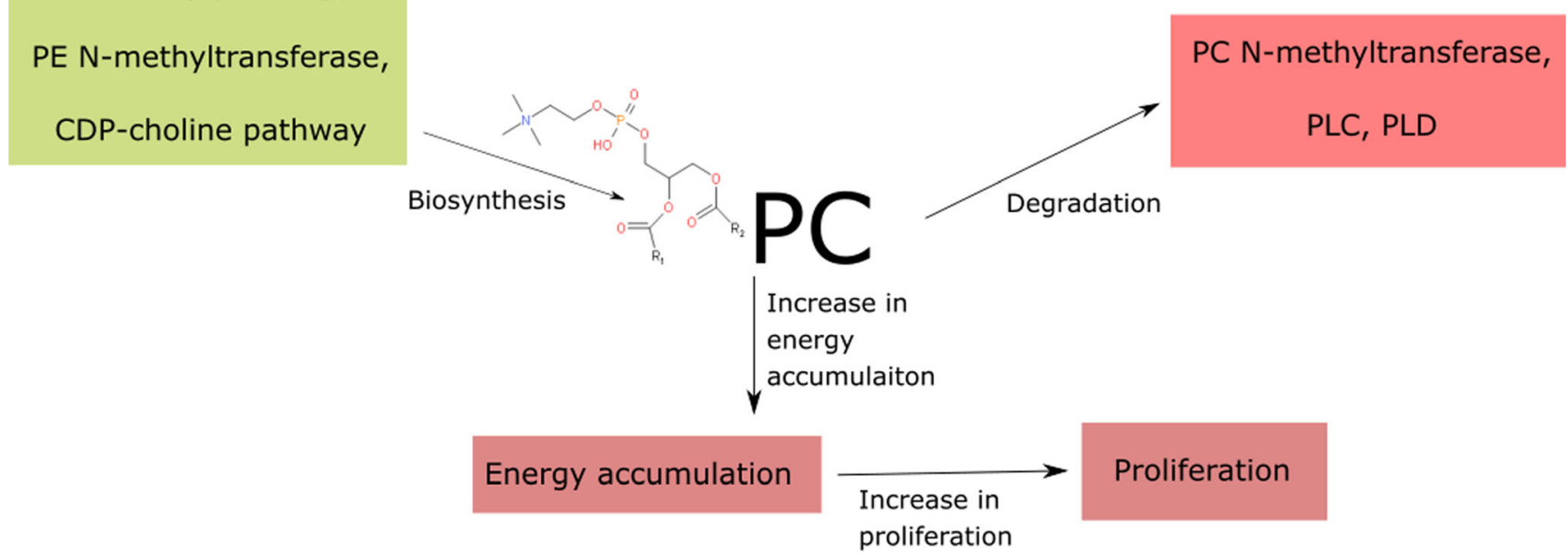

Biological effect

Fig. 6. Phosphatidylcholine (PC) content in the cell membrane increases by the induction of the Kennedy pathway, PE N-methyltransferase and CDP-choline pathway. Conversely, the induction of PC N-methyltransferase, PLC and PLD leads to PC degradation. PC is the easily accessible

in maintaining the proper functioning of the bilayer (Van Meer et al., 2008). The anionic compounds possess entirely different properties from the fully acylated equivalents. Lysophospholipids biosynthesis is mediated by enhanced activity of phospholipase A2 (PLA2), while their degradation is catalysed by other phospholipases, like PLC, PLD or PLA1 (phospholipase A 1). The elevation of lysophosphatidylethanolamine plasma levels is triggered by the plasma PLA2 (Murakami et al., 2015). PLA2 activity stimulation results in lysophosphatidylipids production, leading to the improper membrane curvature and thus its destabilisation (Henriksen et al., 2010). Consequently, plasma membrane leakage may arise. Moreover, in this state, the membrane becomes more susceptible to membrane fusion, making the lysolipids responsible for cell exocytic capacity (Haraszti et al., 2016; Hoen et al., 2016; Leung et al., 1998). The increase in lysophospholipid content is responsible for cancer growth, proliferation, and angiogenesis presumably by enhancing the extracellular phospholipids delivered to the tumour (Yang et al., 2018). Curiously, the elevated level of the lysophospholipid in the tumour microenvironment was proved to be a useful biomarker of ovarian cancer, which could become a potent anti-cancer target in the future $(Y . X u$ 2018). Presented properties explain the minor contribution of lysophospholipids to the membrane lipid profile. To prevent disintegration, the cell can incorporate the lacking fatty acid chains by a specific sn-2-acyltransferase or relocate the lysophospholipids from the plasma membrane to the cytosol (Hishikawa et al., 2008; Shindou et al., 2009).

\section{Membrane cholesterol}

Cholesterol decreases membrane fluidity under physiological conditions (Ayee and Levitan, 2016). The sterol is present on both sides of the membrane, however more it is abundant in the outer leaflet (Liu et al., 2017a). Due to its small molecular volume and excessive hydrophobic interactions with fatty acids, cholesterol increases membrane density (Gracià et al., 2010). Various cell types exhibit different levels of membrane cholesterol, for instance, Jurkat cell line cholesterol remains about $20 \mathrm{~mol} \%$, while breast cancer (MDA-MB-231 cell line) levels reach about $35 \mathrm{~mol} \%$ (Hoejholt et al., 2019). Cholesterol content is directly associated with cell function. Plasma membrane cholesterol is either a product of intracellular biosynthesis or a derivative of plasma lipoproteins. Consequently, any enzyme deficiency in the cholesterol metabolism pathway may result in abnormalities of membrane fluidity (Fig. 7) (Gondré-Lewis et al., 2006). Due to intracellular cholesterol biosynthesis, non-motile breast cancer cells exhibit increased levels of membrane sterols (Ehmsen et al., 2019). Conversely, motile Jurkat cells require lower membrane cholesterol levels to increase plasma membrane flexibility, and thus to improve the ability to infiltrate various tissues.

Cholesterol content plays a key role in membrane fluidity regulation, which modulates the resistance to the chemotherapy and metastatic properties of cancer cells. Cancer cells preparing for metastasis tend to exhibit lower membrane cholesterol levels to maximise membrane fluidity (Yang and Chen 


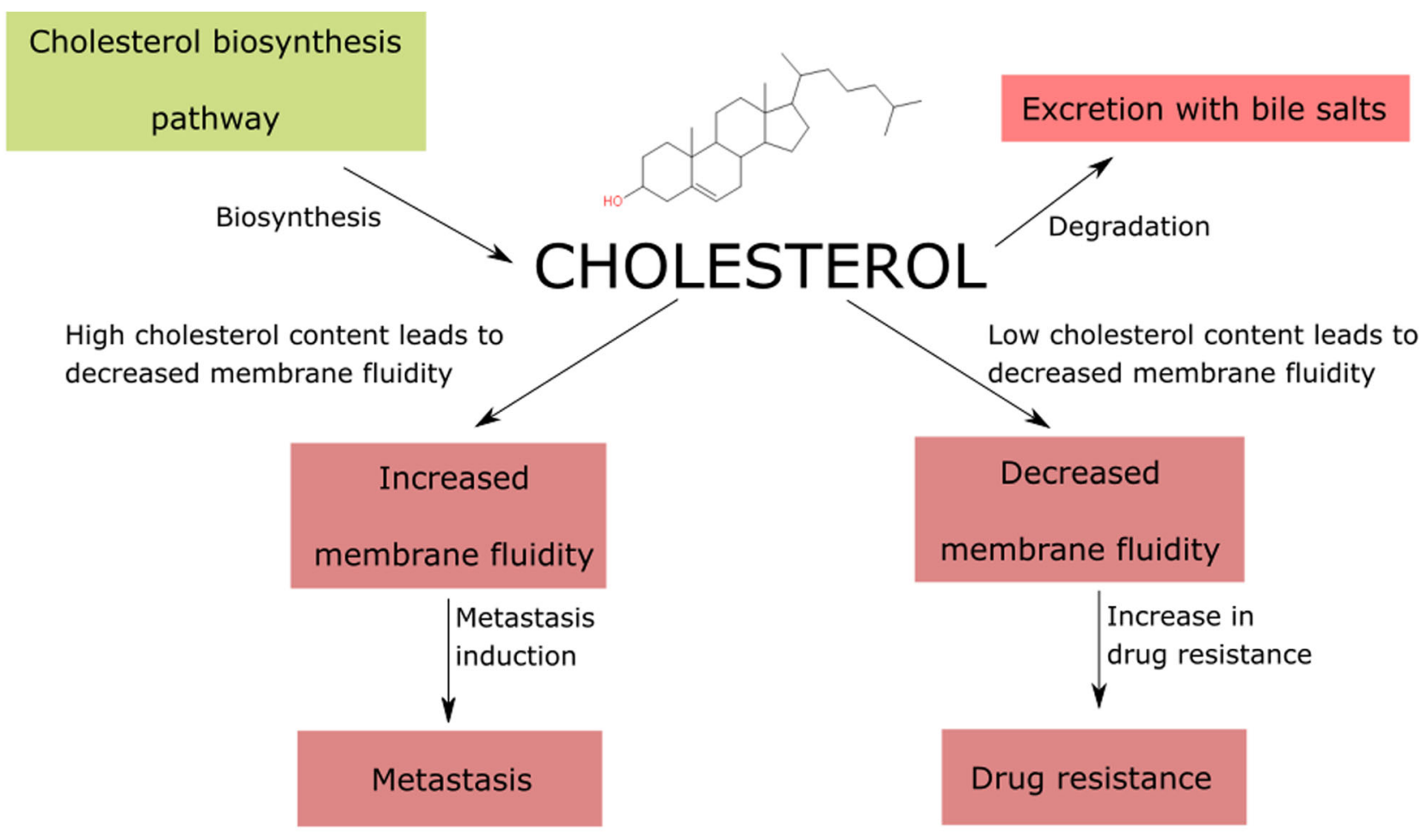

Biological effect

Figure 7. Cholesterol is the key regulator of the membrane's fluidity. The increased membrane rigidity leads to the drug resistance by modulation of xenobiotics transporters and the physical changes in the plasmalemma,

2018; Zhao et al., 2019). This feature enables a neoplastic cell to easily modulate its shape. Conversely, higher membrane cholesterol levels account for chemotherapy resistance (Hutchinson et al., 2018). It has been proven that cells with higher membrane cholesterol concentration tend to exhibit greater drug resistance compared to those with lower cholesterol content (Alves et al., 2016; Peetla et al., 2013). This may arise from the plasma membrane sealing, by the reduction of empty spaces in the lipid bilayer. Interestingly, mitochondrial membranes stiffness seems to be involved in the resistance of neoplastic cells to death signal and the stimulation of the Warburg effect (Ribas et al., 2016). Alterations in cholesterol content to enhance cell adaptation to the unfavourable environment are observed among steroidogenic cells, such as breast or ovarian carcinomas (Chimento et al., 2019).

Cholesterol and sphingomyelin are involved in the formation of membrane lipid rafts (Pike 2004). Lipid rafts are plasma membrane regions with a highly organised lipid composition, which act as specific platforms for integral membrane proteins (IMP) concentration and stabilisation (Simons and Ehehalt, 2002). Flotillin and caveolin are considered as the peptide markers of the lipid rafts (Buschiazzo et al., 2013). The effect of treatment could affect the structure of the raft and modulate the cancer cells, for instance, resveratrol shifts
Conversely, the enhanced fluidity enables the cell to penetrate through the extracellular matrix and circulation.

flotillin from intracellular vesicles to the raft domains in plasmalemma (Gomes et al., 2019). Other research studies indicate that the reduction of plasma cholesterol content results in lipid raft destabilisation and dysfunction of the cells (Buschiazzo et al., 2013). Other lipids are important in raft formation as well. In this case, phospholipid headgroups play a minor role, contrary to fatty acid residues (Fan et al., 2010; Hancock 2006). A degree of fatty acid unsaturation and its chain length are of great importance for raft formation process (Fan et al., 2010). Lipid rafts provide the environment for proteins' oligomerization and enable interactions with other peptides (Hancock 2006). The high-density regions composed of cholesterol and sphingomyelin formate, constitute a proper microenvironment for proteins, which directly spans the membrane (i.e. ion channels, CD95 death receptor, T and B-cell receptors) and for proteins anchored via GPI, like alkaline phosphatase or DAF (decay-accelerating factor) (Brown and Waneck, 1992; Gajate and Mollinedo, 2015; Zech et al., 2009). Rafts also supply the ions channels with cholesterol, which are essential for their proper functioning.

Since the domains are involved in a critical cell cycle processes, such as the control of cell death and survival, they are involved in carcinogenesis (Gajate and Mollinedo, 2015; George and Wu, 2012; Groux-Degroote et al., 2017; 
Zhuang et al., 2005). Molecular studies showed that the disintegration of cholesterol microdomains could be achieved by various lipid-like molecules, like erucylphosphocholine or even lysophospholipids (Wnętrzak et al., 2015). The agents lead to the membrane fluidisation and destabilisation of cancer-associated markers (Wnettrzak et al., 2015). Low cholesterol content results in the improper formation of rafts, defective functioning of adhesion molecules and eventually to metastases (Buschiazzo et al., 2013). Indeed, tumour cells regulate the cholesterol content to allow the migration and decrease the membrane permeability for chemotherapeutics (Mollinedo and Gajate, 2020). For instance, melanoma migration is regulated by changes in lipid rafts (Wang et al., 2013). By Src-RhoA-Rock pathway, cancer cells modulate the actin cytoskeleton, allowing intravasation and migration in the extracellular matrix (Wang et al., 2013). Conversely, as far as the breast cancer cells are concerned, association to the lipid rafts restricts the interaction between CD44 and ezrin (Donatello et al., 2012). In non-invasive cells, CD44 is localised in lipid rafts and ezrin aside from the non-raft regions (Donatello et al., 2012). After the induction of migration, both proteins interact, leading to the metastasis (Donatello et al., 2012).

\section{Membrane sphingolipids}

Sphingolipids are heterogeneous classes of lipids, all of which contain a sphingosine backbone (Van Meer 2005). Sphingolipids include ceramides (sphingosine and fatty acid residue), sphingomyelins (choline or ethanolamine group esterified with a 1-phosphate group of sphingosine) cerebrosides (glucose or galactose attached to $\mathrm{C} 1$ of ceramide) and gangliosides (at least one sialic acid molecule attached to the sugar chain of glycolipid). Each type of the sphingolipids is discussed in the following sections.

\section{Ceramide and its derivatives}

Under physiological conditions, ceramide content in the membrane is negligible, not exceeding $0.5 \mathrm{~mol} \%$ (Zech et al., 2009). Low concentration is a result of ceramide-mediated apoptosis induction (Woodcock 2006). The proapoptotic ceramide pathway begins with neutral sphingomyelinase activation by the factor associated with neutral sphingomyelinase (FAN), that is dependent on the signal from CD95 receptor death domain (DD) (Van Blitterswijk et al., 2003). Ceramide, which is a product of the sphingomyelinase-catalysed reaction, induces cytochrome c release from mitochondria and consequently activates the apoptotic pathway (Mullen and Obeid, 2012). Increased ceramide membrane levels result in inhibition of cancer cell proliferation and proper regulation of the cell cycle (Ogretmen 2017). Therefore, the increased ceramide biosynthesis appears to be harmless, or even has therapeutic potential (Woodcock 2006). Some novel strategies of cancer therapies aim to overexpress the ceramide biosynthetic pathway enzymes and eventually lead to programmed cancer cell death (Moro et al., 2019). Enzymes utilised in cancer treatment include serine C-palmitoyl transferase (CPT) - sensitising breast cancer cells to chemotherapy (Wang et al., 2002), ceramide synthase 1 (CERS1) - inducing mitophagy and acute myeloid leukaemia (AML) cell death (Dany et al., 2016), ceramide synthase 6 (CERS6) - modulating caspase activation in head and neck cancer (WhiteGilbertson et al., 2009), dihydroceramide desaturase (DES) leading to cell cycle arrest in neuroblastoma cells (Kraveka et al., 2007), acidic sphingomyelinase (ASMase) - inducing lymphoblasts apoptosis (Santana et al., 1996) and neutral sphingomyelinase (NSMase) - utilised in breast cancer therapy (Hwang et al., 2015).

Malfunction or overexpression of enzymes involved in the ceramide degradation pathway results in cell cycle dysregulation and apoptosis impairment, which could eventually lead to carcinogenesis (Huang et al. 2011). Increased activity of enzymes catalysing pro-malignant sphingolipids formation reactions, such as glutamate-cysteine ligase (GCL) (Li et al. 2014), spermine synthase (SMS) (Massaro et al., 2017), sphingosine kinase (SphK) (Hatoum et al., 2017) and ceramide kinase (CERK) (Payne et al., 2014) results in the apoptosis escape and cancer progression. Excessive transport of ceramide from the endoplasmic reticulum to the Golgi apparatus is considered as pro-cancerous by separating the antiapoptotic lipid from the cell membrane (Hanada 2010; Liu et al., 2017b).

Plasma membrane bilayer contains various amounts of sphingomyelin, oscillating between 3 mol\% in Jurkat, HT29, MDA-MB-231 and fibroblast cell lines, as well as up to $15 \mathrm{~mol} \%$ in nerve cells (Hoejholt et al., 2019; Slotte and Ramstedt, 2007). Sphingomyelin is found on both sides of the membrane, with a higher concentration in the outer leaflet (Van Meer et al., 2008). Most lipids consist of a sphingosine chain with the oleic acid residue attached (Hoejholt et al., 2019). Sphingomyelin biosynthesis involves sphinganine synthesis, further acylation to dihydroceramide and eventually dehydrogenation (Jiang et al., 2009). Conversely, sphingomyelin breakdown results in ceramide release.

Sphingomyelin induces an increase in resistance to chemotherapy, by P-glycoprotein trafficking to plasma membrane lipid rafts and the increase in cell membrane integrity (Modok et al., 2004; Slotte and Ramstedt, 2007). Besides, the increased level of sphingomyelin act as a tumourpromoting factor (Zheng et al., 2019). This pro-malignant activity arises from the decrease of pro-apoptotic ceramide (Woodcock 2006). Moreover, sphingomyelin has been identified as a negative regulator of autophagy by impairing autophagosomes organisation, normally modulated by autophagy-related protein 9A (ATG9A) (Fig. 8) (CorcelleTermeau et al., 2016). 


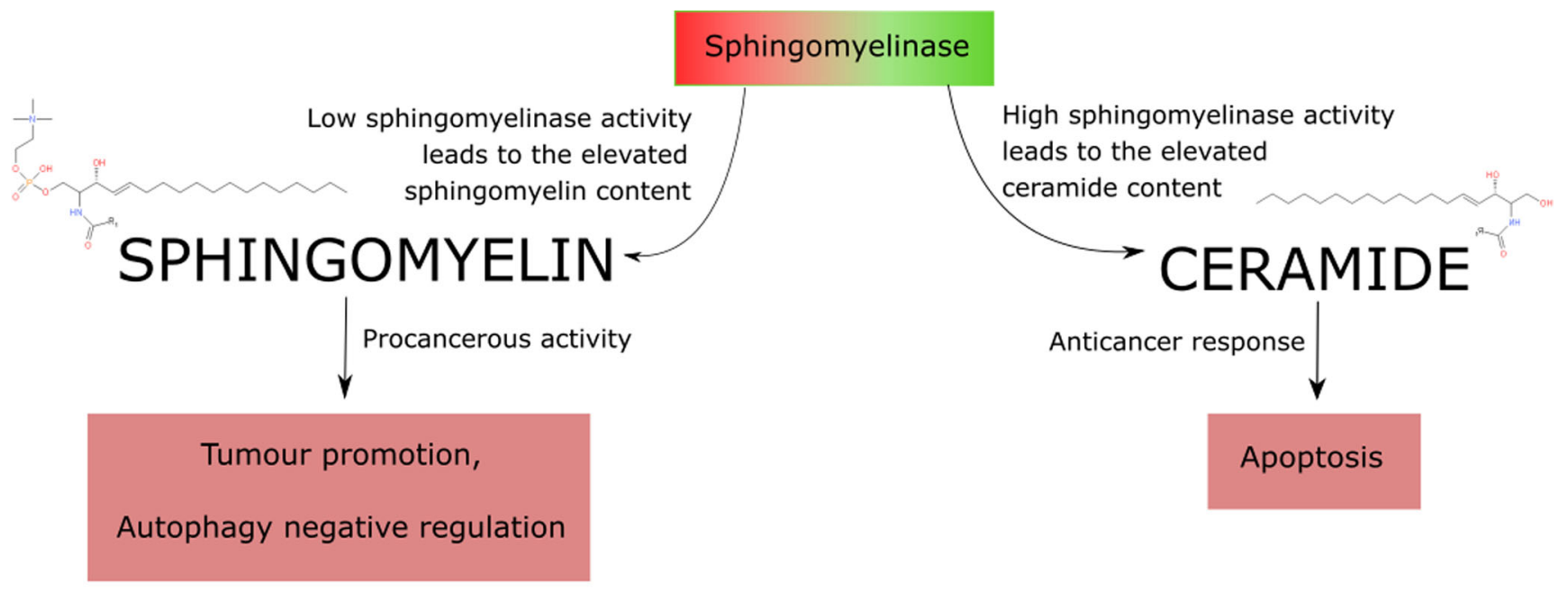

Fig. 8. Sphingomyelin and ceramide metabolism is regulated by sphingomyelinase activity. The catalysis of choline detachment leads to cell apoptosis. However, in cancer cells, the sphingomyelinase activity is

Sphingosine 1-phosphate (S1P) is considered to be a tumourpromoting factor, as its elevated level promote proliferation, therapy resistance, and metastatic spread (Guo et al., 2015; Tsuchida et al., 2017). It is formed by sphingosine phosphorylation, catalysed by two isoforms of sphingosine kinase - intracellular (SPHK1) and nuclear (SPHK2) (Hatoum et al., 2017). S1P acts either on a receptor-dependent (S1PR) or on a fully independent pathway (Park et al., 2013). The independent pathway involves S1P interaction with histone deacetylase (HDAC) resulting in enhanced activity of human telomerase reverse transcriptase (hTERT), finally leading to infinite cell proliferation (Panneer Selvam et al., 2015). Moreover, angiogenesis may be stimulated by the interaction of S1P with peroxisome proliferator-activated receptor- $\gamma$ (PPAR $\gamma$ ) (Parham et al., 2015). Eventually, S1P accelerates cell proliferation by activating the NF- $\mathrm{KB}$ factor on both TNFR-associated factor 2 (TRAF2) and receptorinteracting protein 1 (RIPK1) pathways (Alvarez et al., 2010; Park et al., 2015). Besides, S1P- inhibits caspase-3 and protein phosphatase 2A (PP2A) as well as induces autophagy (Fig. 9) (Watters et al., 2011).

\section{Glycosphingolipids}

Glycosphingolipids could be divided into two general categories: cerebrosides with a single monosaccharide residue, and gangliosides with at least one sialic acid residue attached to the ceramide (Yeagle 2016). Glycolipids are localised in the outer leaflet of the plasma membrane, with the glycan chains exposed to the extracellular space (Van Meer et al., 2008). Depending on the sugar residue attached, cerebrosides could be further categorised as gluco- and galactocerebrosides. A high concentration of cerebroside in the plasma membrane may act upregulated and results in the sphingomyelin extensive accumulation. The lipid enables tumor progression and autophagy negative regulation.

as a metastatic and antiapoptotic signal (Liu et al., 2013). Cells with elevated cerebroside level tend to be more chemotherapyresistant than those with physiological cerebroside content, due to the induction of p53 gene expression (Hosain et al., 2016). The chemotherapy resistance mechanism involves direct activation of c-Src (Proto-oncogene tyrosine-protein kinase) and $\beta$ catenin signalling pathway by cell membrane cerebrosides ( $\mathrm{Liu}$ et al., 2010). This results in upregulation of multidrug resistance gene 1 (MDR1) expression as well (Ghandadi et al., 2019). Cerebrosides levels rise in numerous cancer cell lines, as an effect of glucosyl- and galactosyltransferase overexpression (Chuang et al., 2019; Zhu et al., 2005).

In non-malignant human cells, gangliosides consist of acetyl (NeuAc) or glycol group (NeuGc) attached to the neuraminic acid by an N-glycosidic bond (Asakawa et al., 2006; Chammas et al., 1999). The acetyl substituent is predominant under physiological conditions (Asakawa et al., 2006; Chammas et al., 1999). However, cancer cells produce an excess of gangliosides that contain glycol groups (Krengel and Bousquet, 2014). The changes in gangliosides number and structure occur also during embryogenesis (Breimer et al., 2017).

In general, a greater number of gangliosides in the lipid bilayer is associated with enhanced invasive properties of cancer (Groux-Degroote et al., 2017). Studies indicate that melanoma cells exhibit significantly higher ganglioside GD3 levels in comparison to non-malignant melanocytes (Pukel et al., 1982). Other neoplastic cells also express specific gangliosides, such as GD2, on the surface of leukemic T-cells (Furukawa et al., 1993). Overexpression of neoplastic gangliosides also results in tumour-specific immune response inhibition via interaction with Siglec-7 protein (Kawasaki et al., 2010). Moreover, cancer cells tend to release large amounts of gangliosides to the neoplastic 


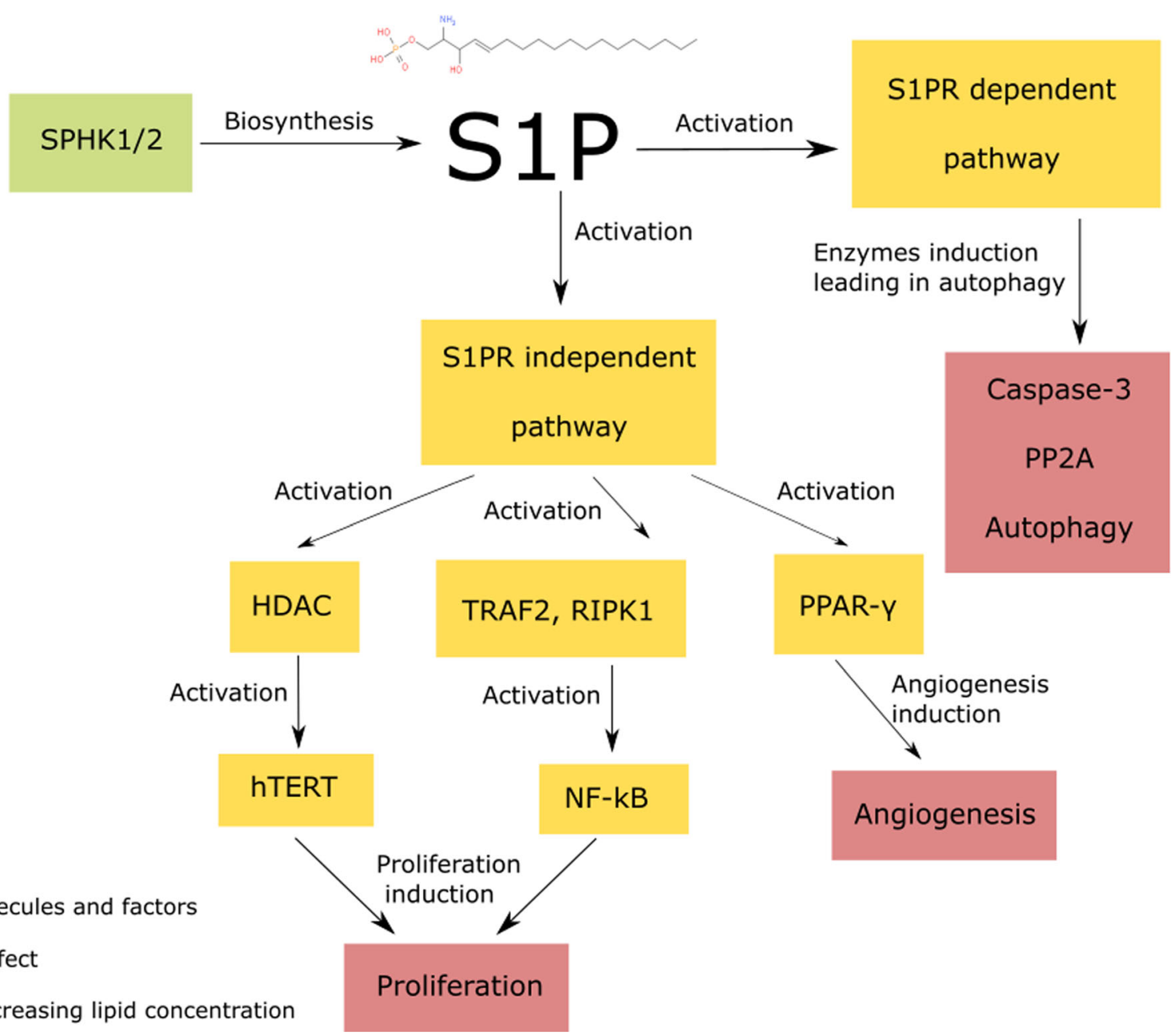

Fig. 9 Sphingosine-1-phosphate (S1P) acts in both S1PR dependent and independent pathways. The induction of S1PR dependent pathway leads to the autophagy induction. The S1PR independent pathway activity results in increased angiogenesis and cancer proliferation; SPHK $1 / 2$ sphingosine-1-phosphate kinase 1/2, S1PR - sphingosine-1-phosphate receptor, HDAC - histone deacetylase, hTERT - human telomerase reverse transcriptase, TRAF2 - TNF receptor-associated factor 2, RIPK1 receptor-interacting serine/threonine-protein kinase $1, \mathrm{NF}-\mathrm{kB}$ - nuclear factor $\mathrm{kB}$, PPAR $-\gamma$ - peroxisome proliferator-activated receptor $\gamma, \mathrm{S} 1 \mathrm{PR}$ - sphingosine-1-phosphate receptor, PP2A - protein phosphatase 2A; microenvironment (Chung et al., 2017). Interactions with ganglioside receptors on the surface are crucial for vascular endothelial growth factor (VEGF) signalling pathway activation, resulting in angiogenesis (Lang et al., 2001). Mutations or altered expression of genes involved in ganglioside biosynthetic pathways result in ganglioside membrane levels abnormalities. Despite the great importance of gangliosides and cerebrosides in cancer development, it should be remembered that the lipids act also as antigens, and therefore their role may be much more complex (Chung et al., 2017).

\section{Relationship between degree of unsaturation and neoplasia}

Fatty acid residues may differ from one another by the degree of unsaturation, as well as the location of double bonds (Rodwell et al., 2015). Bearing in mind that under physiological conditions fatty acids contain double bonds in the cis configuration, unsaturated lipids tend to increase the volume of the plasma membrane, simultaneously decreasing its density (Ollila et al., 2007). Moreover, a high content of unsaturated fatty acids, makes the cell membranes more susceptible to lipid peroxidation (Porter et al., 1995).

Interestingly, plasma membrane in cancer cells exhibits a different degree of unsaturation than that in non-malignant cells (Li et al., 2017; Mason et al., 2012; Peck et al., 2016). To protect plasma membrane lipids peroxidation, cancer cells maintain a lower degree of unsaturation (Beloribi-Djefaflia et al., 2016; Peck et al., 2016). Moreover, a higher concentration of saturated fatty acids in the lipid bilayer results in an increased stability of lipid raft domains, resulting in greater protein binding capacity of the membrane (Beloribi-Djefaflia et al., 2016). 
Nevertheless, not all cancerous cells show increased saturated or monounsaturated fatty acids content. Cancer stem cells (CSCs) usually exhibit a higher degree of unsaturation as compared to non-malignant cells ( $L i$ et al., 2017). Nuclear factor $\mathrm{kB}$ (NF-KB), directly regulates the expression of CSCs lipid desaturase, which catalyses the conversion of saturated into unsaturated fatty acids with cytochrome b5/NADH cytochrome b5 reductase electron transfer system support (Mukherjee et al., 2017). Polyunsaturated fatty acids promote the expression of CSCs markers, aldehyde dehydrogenase (ALDH) and CD133 among cancer cells with CSCs phenotype (Yi et al., 2018).

\section{Lipid membranes as a therapeutic target}

Nowadays, the lipid content of the cancer cell is pharmacologically modulated, as a part of clinical management (Luo et al., 2018). The regulation of lipid metabolism is especially effective among carcinomas with highly altered lipid content. The therapy does not only concern the plasma membrane lipids, but also the intracellular membranes, such as the endoplasmic reticulum or Golgi apparatus (Shyu et al., 2018). Drugs used in lipid-targeting therapies could be divided into two groups.

The first group consists of drugs that specifically affect the lipid or its metabolism (Cheng et al., 2016; Tan et al., 2017). Due to the fact that the targeted lipids build all the cells in the body, the therapy has to be very specific affecting only a certain lipid and carried out in elevated concentrations range (Tan et al., 2017). In this field researchers particularly focus on the design and production of very specific proteins or small-molecule compounds to omit the severe systemic complications of the therapies (Srivatsav et al. 2018; Bernardes and Fialho, 2018; Yan Lim and Yee Kwan, 2018). As discussed before, the therapy results in the changes in the cell membranes properties, resulting in carcinogenesis, metastases and drug resistance decrease (Frimpong 2019; Zalba and ten Hagen, 2017). To maintain the desired specificity during chemotherapy, it is required to use drugs that target certain lipid metabolism (Cheng et al., 2016; Tan et al., 2017). Such an approach was effectively applied for carcinomas, lipid metabolism dysregulation diseases, such as ovarian cancer, sarcomas or even pancreatic endocrine tumours (Manara et al., 2010; Soler et al., 2016; Xie et al., 2017).

The second group of lipid-lowering drugs, which have been proved to have anticancer properties are statins (i.e. Lovastatin) (Peng et al., 2017). The mechanism statins action involves the disruption of cholesterol biosynthesis, decrease of cell proliferation and survival (Martirosyan et al., 2010). From the histological point of view, the changes being a consequence of the therapy include a lack of lipid droplets in the affected cells (Gbelcová et al., 2013). This approach was effectively used among carcinomas with high membrane cholesterol content, such as breast cancer (Borgquist et al., 2018). Interestingly, clinical metanalysis of cancer incidence among patients treated with statins showed an increased probability of high-grade prostate cancer diagnosis
(Nordström et al., 2015). Moreover, Shepherd et al. proved that patients treated with pravastatin were more frequently diagnosed with cancer in comparison to the placebo-treated group (Shepherd et al., 2002). Aside from the pro-cancerous effects, statin use in chemotherapy meets obstacles, such as the use of high doses (500 times higher than standard hypercholesterolemia treatment) of the drug (Dulak and Józkowicz, 2005). The high anticancer concentration of the drug leads to the statin-induced rhabdomyolysis (Hu et al., 2012). Therefore, statins could be used as adjuvant therapy for cancer treatment in the mevalonate pathway targeting (Mo et al., 2019). The blockage of mevalonic acid synthesis leads to the deactivation of isoprenoid-composed G-protein-coupled proteins, such as Ras, Rho and Rac (Vallianou et al., 2014). Additionally, statins could enhance the effects of the immune response towards cancer by increasing the antigen presentation by dendritic cells (Bird 2018).

The most current management aims to block the uptake, intracellular lipolysis and utilisation of lipids (Diao and Lin, 2019). This approach was introduced, when researchers found that cancer cells are characterised by high energy demand for proliferation (Long et al., 2018). Overexpression of lipid uptake receptors (like CD36) in the tumour came out to be an effective target to suppress cancer growth and progression (Pascual et al., 2017). A distinction of the lipid composition of the cell membrane in various types of cancer cells might be useful in the planning of anticancer strategy. The exemplary profiles according to the available data are presented in Table 1.

Table 1 Cell membrane lipid composition based on the lipidomic studies of the cell membrane of various cell lines

\begin{tabular}{lllll}
\hline Lipid [mol\%] & $\begin{array}{l}\text { HT- } \\
\mathbf{2 9}\end{array}$ & $\begin{array}{l}\text { MDA- } \\
\text { MB231 }\end{array}$ & $\begin{array}{l}\text { HDF- } \\
\text { n }\end{array}$ & Jurkat \\
\hline PA & 0.5 & 0.5 & 0.5 & 0.3 \\
PI & 4 & 4 & 4 & 12.5 \\
PG & 0.5 & 0.5 & 0.5 & 0.3 \\
PS & 4 & 4 & 4 & 7.5 \\
PE & 2 & 4 & 8 & 14 \\
PC & 9.5 & 13 & 20.25 & 40 \\
PE eter & 7.25 & 10.5 & 7.75 & 3 \\
PC eter & 16.75 & 1.5 & 0.25 & 3.4 \\
SM & 2.5 & 8.3 & 5.83 & 4 \\
DAG & 45.8 & 51.7 & 45.8 & 0.5 \\
Chol & & & & 23 \\
HexCer & & & & 0.1 \\
diHexCer & & & & 0.01 \\
\hline
\end{tabular}

HT-29 - colon cancer, MDA-MB231 - breast cancer, HDF-n - human dermal fibroblasts, Jurkat - T-cell leukaemia. mol\% values correspond to the approximate values of each lipid. PA - phosphatidic acid, PI - phosphatidylinositol, PG - phosphatidylglycerol, PS - phosphatidylserine, PE phosphatidylethanolamine, PC - phosphatidylcholine, SM sphingomyelin, DAG - diacylglycerol, Chol - cholesterol, HexCer hexosylceramides, diHexCer - dihexosylceramides 
Presented data, show an increased PI level in Jurkat cell line. The extent of PI leads to cancer cells proliferation and changes in G-protein mediated signalling pathways. The hypothetical therapy approach would include Ras or Rho inhibitors. Indeed, molecular and clinical data, prove the high contribution of Ras in leukaemia (Kindler et al., 2008; Pasmant et al., 2015). Moreover, Ras inhibitor - farnesyl thyosalicylic acid was successfully used to sensitise the T-cell leukemic cells to apoptosis signal (Stoppa et al., 2012). According to the data presented in Table 1, PC, PS and PE depleting agents could potentially be useful to target leukaemia cells. In the case of PS, fingolimod (FTY720) was successfully used to induce phosphatidylserine externalisation, thus leading to cell death (Young et al., 2019). No clinical data could be found in the field of PC or PE depletion, however, in vitro research showed the potency of trans, trans-farnesol (PC uptake inhibitor) in death induction in leukemic cells (Melnykovych et al., 1992). Conversely, the excess of cholesterol was proved to be a potential therapeutic target in breast cancer treatment ( $L i$ et al., 2006). On the other hand, its depletion together with metformin and methyl- $\beta$-cyclodextrin resulted in the reduced migration and cell death induction (Guerra et al., 2016; Sharma et al., 2019).

Inhibition of lipid biosynthesis and its uptake provides the physicians with a complete set of tools and possibilities to modulate the lipid composition of the cancer cell.

\section{Summary}

Lipid profile may be considered as a crucial prognostic factor in cancer patients. Quantitative changes in lipids are observed in all neoplastic cells as compared to non-malignant cells. Therefore, some lipids (e.g. phosphatidylcholine) may be considered as tumour markers in certain malignancies. Alternations in the main groups of the membrane lipids are mostly associated with activation and inactivation of cellular signalling pathways. In some cases, the changes result in the metabolic reprogramming of tumour cells. On the other hand, alterations made to fatty acids chains length and their degree of unsaturation, change the physical properties of cell membrane - either increasing its fluidity or stabilising membrane proteins in the lipid rafts. Additionally, a significant role in cancer therapy resistance mechanisms and metastases is played by cholesterol which is responsible for membrane fluidity regulation..

There is still much to be discovered on the lipid composition of the cancer cell membrane, however, the current knowledge can already be successfully utilised in cancer treatment.

Author's contributions Idea for the article WS, literature search and data analysis WS, IZ and AZ, supervised and critically revised the work MT and JK.
Funding information This research was funded by the National Science Centre (Poland) within a framework of SONATA BIS 6 (2016/22/E/NZ5/ 00671; PI: J. Kulbacka).

\section{Compliance with ethical standards}

Conflict of interest The authors declare no conflict of interest.

Open Access This article is licensed under a Creative Commons Attribution 4.0 International License, which permits use, sharing, adaptation, distribution and reproduction in any medium or format, as long as you give appropriate credit to the original author(s) and the source, provide a link to the Creative Commons licence, and indicate if changes were made. The images or other third party material in this article are included in the article's Creative Commons licence, unless indicated otherwise in a credit line to the material. If material is not included in the article's Creative Commons licence and your intended use is not permitted by statutory regulation or exceeds the permitted use, you will need to obtain permission directly from the copyright holder. To view a copy of this licence, visit http://creativecommons.org/licenses/by/4.0/.

\section{References}

Alvarez SE, Harikumar KB, Hait NC, Allegood J, Strub GM, Kim EY, Maceyka M, Jiang H, Luo C, Kordula T, Milstien S, Spiegel S (2010) Sphingosine-1-phosphate is a missing cofactor for the E3 ubiquitin ligase TRAF2. Nature 465(7301):1084-1088. https://doi. org/10.1038/nature09128

Alves, A. C., Ribeiro, D., Nunes, C., \& Reis, S. (2016). Biophysics in cancer: The relevance of drug-membrane interaction studies. Biochim. Biophys. Acta - Biomembr. Elsevier B.V. https://doi.org/ 10.1016/j.bbamem.2016.06.025

Arikketh D, Nelson R, Vance JE (2008) Defining the importance of phosphatidylserine synthase-1 (PSS1): Unexpected viability of PSS1-deficient mice. J. Biol. Chem. 283(19):12888-12897. https://doi.org/10.1074/jbc.M800714200

Arlauckas, S. P., Popov, A. V., \& Delikatny, E. J. (2016). Choline kinase alpha - Putting the ChoK-hold on tumor metabolism. Prog. Lipid Res. Elsevier Ltd. 1https://doi.org/10.1016/j.plipres.2016.03.005

Arun SN, Xie D, Howard AC, Zhong Q, Zhong X, McNeil PL, Bollag WB (2013) Cell wounding activates phospholipase D in primary mouse keratinocytes. J. Lipid Res. 54(3):581-591. https://doi.org/ 10.1194/jlr.M027060

Asakawa H, Sasabe M, Miyazaki R, Matsuda H, Fukai F, Hanada K et al (2006) The analysis of N-glycolylneuraminic acid(NeuGc) of hepatoma tissue and K562 cell ferritins using HPLC and mass spectrometry. Proc. Jpn. Acad. Ser. B. Phys. Biol. Sci. 82(5):181-187. https://doi.org/10.2183/pjab.82.181

Ayee, M. A., \& Levitan, I. (2016). Paradoxical impact of cholesterol on lipid packing and cell stiffness. Front. Biosci. (Landmark Ed., 21, 1245-59. Retrieved from http://www.ncbi.nlm.nih.gov/pubmed/ 27100504

Bailey LJ, Choudhary V, Bollag WB (2017) Possible Role of Phosphatidylglycerol-Activated Protein Kinase C- $\beta$ II in Keratinocyte Differentiation. Open Dermatol J. 11(1):59-71. https://doi.org/10.2174/1874372201711010059

Baldanzi G, Cutrupi S, Chianale F, Gnocchi V, Rainero E, Porporato P et al (2008) Diacylglycerol kinase- $\alpha$ phosphorylation by Src on Y335 is required for activation, membrane recruitment and Hgfinduced cell motility. Oncogene 27(7):942-956. https://doi.org/10. 1038/sj.onc. 1210717 
Baldanzi G, Mitola S, Cutrupi S, Filigheddu N, Van Blitterswijk WJ, Sinigaglia $\mathrm{F}$ et al (2004) Activation of diacylglycerol kinase $\alpha$ is required for VEGF-induced angiogenic signaling in vitvo. Oncogene 23(28):4828-4838. https://doi.org/10.1038/sj.onc. 1207633

Bebber, C. M., Müller, F., Clemente, L. P., Weber, J., \& von Karstedt, S. (2020). Ferroptosis in cancer cell biology. Cancers (Basel). MDPI AG. https://doi.org/10.3390/cancers12010164

Beloribi-Djefaflia S, Vasseur S, Guillaumond F (2016) Lipid metabolic reprogramming in cancer cells. Oncogenesis 5(1):e189-e189. https://doi.org/10.1038/oncsis.2015.49

Belzile O, Huang X, Gong J, Carlson J, Schroit A, Brekken R, Freimark B (2018) Antibody targeting of phosphatidylserine for the detection and immunotherapy of cancer. ImmunoTargets Ther 7:1-14. https:// doi.org/10.2147/ITT.S134834

Bernardes N, Fialho AM (2018) Perturbing the dynamics and organization of cell membrane components: A new paradigm for cancertargeted therapies. Int. J. Mol. Sci. MDPI AG. https://doi.org/10. 3390/ijms 19123871

Bird L (2018) Statins as adjuvants. Nat. Rev. Immunol. Nature Publishing Group. https://doi.org/10.1038/s41577-018-0076-5

Birge RB, Boeltz S, Kumar S, Carlson J, Wanderley J, Calianese D et al (2016) Phosphatidylserine is a global immunosuppressive signal in efferocytosis, infectious disease, and cancer. Cell Death Differ. Nature Publishing Group. https://doi.org/10.1038/cdd.2016.11

Björkholm P, Ernst AM, Hacke M, Wieland F, Brügger B, Von Heijne G (2014) Identification of novel sphingolipid-binding motifs in mammalian membrane proteins. Biochim. Biophys. Acta - Biomembr. 1838(8):2066-2070. https://doi.org/10.1016/j.bbamem.2014.04. 026

Bleijerveld OB, Brouwers JFHM, Vaandrager AB, Helms JB, Houweling M (2007) The CDP-ethanolamine pathway and phosphatidylserine decarboxylation generate different phosphatidylethanolamine molecular species. J. Biol. Chem. 282(39):28362-28372. https://doi. org/10.1074/jbc.M703786200

Bogdanov M, Dowhan W (1998) Phospholipid-assisted protein folding: phosphatidylethanolamine is required at a late step of the conformational maturation of the polytopic membrane protein lactose permease. EMBO J. 17(18):5255-5264. https://doi.org/10.1093/emboj/ 17.18.5255

Borgquist S, Bjarnadottir O, Kimbung S, Ahern TP (2018) Statins: a role in breast cancer therapy? J. Intern. Med. Blackwell Publishing Ltd. https://doi.org/10.1111/joim.12806

Brandenburg, L. O., Pufe, T., \& Koch, T. (2014). Role of phospholipase $\mathrm{D}$ in G-protein coupled receptor function. Membranes (Basel). MDPI AG. https://doi.org/10.3390/membranes4030302

Breimer ME, Säljö K, Barone A, Teneberg S (2017) Glycosphingolipids of human embryonic stem cells. Glycoconj. J. Springer New York LLC. https://doi.org/10.1007/s10719-016-9706-y

Brindley DN, Waggoner DW (1996) Phosphatidate phosphohydrolase and signal transduction. Chem. Phys. Lipids 80(1-2):45-57. https://doi.org/10.1016/0009-3084(96)02545-5

Brindley DN, Waggoner DW (1998) Mammalian lipid phosphate phosphohydrolases. J. Biol. Chem. Am Soc Biochem Mole Biol. https://doi.org/10.1074/jbc.273.38.24281

Brown D, Waneck GL (1992) Glycosyl-phosphatidylinositol-anchored membrane proteins. J. Am. Soc. Nephrol. 3(4):895-906 Retrieved from http://www.ncbi.nlm.nih.gov/pubmed/1450366

Budha, S., Giese, R., Gupta, A., De Henau, O., Zappasodi, R., Campesato, L. F., ... Merghoub, T. (2018). Phosphatidylserine targeting antibody in combination with tumor radiation and immune checkpoint blockade promotes anti-tumor activity in mouse B16 melanoma. J. Immunol., 200(1 Supplement).

Buschiazzo J, Ialy-Radio C, Auer J, Wolf JP, Serres C, Lefèvre B, Ziyyat A (2013) Cholesterol Depletion Disorganizes Oocyte Membrane
Rafts Altering Mouse Fertilization. PLoS One 8(4). https://doi.org/ 10.1371/journal.pone.0062919

Casares D, Escribá PV, Rosselló CA (2019) Membrane Lipid Composition: Effect on Membrane and Organelle Structure, Function and Compartmentalization and Therapeutic Avenues. Int. J. Mol. Sci. 20(9):2167. https://doi.org/10.3390/ijms20092167

Chammas R, Sonnenburg JL, Watson NE, Tai T, Farquhar MG, Varki NM, Varki A (1999) De-N-acetyl-gangliosides in humans: unusual subcellular distribution of a novel tumor antigen. Cancer Res. 59(6): 1337-1346 Retrieved from http://www.ncbi.nlm.nih.gov/pubmed/ 10096568

Cheng M, Bhujwalla ZM, Glunde K (2016) Targeting phospholipid metabolism in cancer. Front. Oncol. Frontiers Media S.A. https://doi. org/10.3389/fonc. 2016.00266

Chimento A, Casaburi I, Avena P, Trotta F, De Luca A, Rago V et al (2019) Cholesterol and its metabolites in tumor growth: Therapeutic potential of statins in cancer treatment. Front. Endocrinol. (Lausanne). Frontiers Media S.A. https://doi.org/10.3389/fendo. 2018.00807

Chuang PK, Hsiao M, Hsu TL, Chang CF, Wu CY, Chen BR et al (2019) Signaling pathway of globo-series glycosphingolipids and $\beta 1,3-$ galactosyltransferase V ( $\beta 3$ GalT5) in breast cancer. Proc. Natl. Acad. Sci. U. S. A. 116(9):3518-3523 https://doi.org/10.1073/ pnas. 1816946116

Chung TW, Choi HJ, Park MJ, Choi HJ, Lee SO, Kim KJ et al (2017) The function of cancer-shed gangliosides in macrophage phenotype: Involvement with angiogenesis. Oncotarget 8(3):4436-4448. https://doi.org/10.18632/oncotarget.13878

Cocco L, Faenza I, Fiume R, Maria Billi A, Gilmour RS, Manzoli FA (2006, May) Phosphoinositide-specific phospholipase C (PI-PLC) $\beta 1$ and nuclear lipid-dependent signaling. Biochim. Biophys. Acta Mol. Cell Biol. Lipids. https://doi.org/10.1016/j.bbalip.2006.03.001

Conrad M, Kagan VE, Bayir H, Pagnussat GC, Head B, Traber MG, Stockwell BR (2018, May 1) Regulation of lipid peroxidation and ferroptosis in diverse species. Genes Dev. Cold Spring Harbor Laboratory Press. https://doi.org/10.1101/gad.314674.118

Corcelle-Termeau E, Vindeløv SD, Hämälistö S, Mograbi B, Keldsbo A, Bräsen JH et al (2016) Excess sphingomyelin disturbs ATG9A trafficking and autophagosome closure. Autophagy 12(5):833-849. https://doi.org/10.1080/15548627.2016.1159378

Dany M, Gencer S, Nganga R, Thomas RJ, Oleinik N, Baron KD et al (2016) Targeting FLT3-ITD signaling mediates ceramide-dependent mitophagy and attenuates drug resistance in AML. Blood 128(15): 1944-1958. https://doi.org/10.1182/blood-2016-04-708750

Dawaliby R, Trubbia C, Delporte C, Noyon C, Ruysschaert JM, Van Antwerpen P, Govaerts C (2016) Phosphatidylethanolamine is a key regulator of membrane fluidity in eukaryotic cells. J. Biol. Chem. 291(7):3658-3667. https://doi.org/10.1074/jbc.M115. 706523

Diao X, Lin T (2019) Progress in therapeutic strategies based on cancer lipid metabolism. Thorac. Cancer. https://doi.org/10.1111/17597714.13146

Donatello S, Babina IS, Hazelwood LD, Hill ADK, Nabi IR, Hopkins AM (2012) Lipid raft association restricts CD44-ezrin interaction and promotion of breast cancer cell migration. Am. J. Pathol. 181(6):2172-2187. https://doi.org/10.1016/j.ajpath.2012.08.025

Du J, Zhou Y, Li Y, Xia J, Chen Y, Chen S et al (2020) Identification of Frataxin as a regulator of ferroptosis. Redox Biol. 32:101483. https://doi.org/10.1016/j.redox.2020.101483

Dulak J, Józkowicz A (2005) Anti-angiogenic and anti-inflammatory effects of statins: relevance to anti-cancer therapy. Curr. Cancer Drug Targets 5(8):579-594. https://doi.org/10.2174/ 156800905774932824

Ehmsen S, Pedersen MH, Wang G, Terp MG, Arslanagic A, Hood BL et al (2019) Increased Cholesterol Biosynthesis Is a Key Characteristic of Breast Cancer Stem Cells Influencing Patient 
Outcome. Cell Rep. 27(13):3927-3938.e6. https://doi.org/10.1016/ j.celrep.2019.05.104

Engelking, L. R., \& Engelking, L. R. (2015). Chapter 59 - Sphingolipids. Textb. Vet. Physiol. Chem., 378-383. https://doi.org/10.1016/B9780-12-391909-0.50059-1

Fahy E, Cotter D, Sud M, Subramaniam S (2011) Lipid classification, structures and tools. Biochim. Biophys. Acta - Mol. Cell Biol. Lipids 1811(11):637-647. https://doi.org/10.1016/j.bbalip.2011.06. 009

Falkenburger, B. H., Jensen, J. B., Dickson, E. J., Suh, B. C., \& Hille, B. (2010). Phosphoinositides: Lipid regulators of membrane proteins. In Journal of Physiology (Vol. 588, pp. 3179-3185). WileyBlackwell. https://doi.org/10.1113/jphysiol.2010.192153

Fan J, Sammalkorpi M, Haataja M (2010) Formation and regulation of lipid microdomains in cell membranes: Theory, modeling, and speculation. FEBS Lett. https://doi.org/10.1016/j.febslet.2009.10.051

Frimpong, M. (2019). Modulating Lipid Composition in Cancer Cell-An Alternative Way to Augment Cancer Treatment. Int. J. Lipid Res., $1(1)$.

Furukawa K, Akagi T, Nagata Y, Yamada Y, Shimotohno K, Cheung NK et al (1993) GD2 ganglioside on human T-lymphotropic virus type Iinfected T cells: possible activation of beta-1,4-Nacetylgalactosaminyltransferase gene by p40tax. Proc. Natl. Acad. Sci. USA 90(5):1972-1976. https://doi.org/10.1073/pnas.90.5.1972

Gajate C, Mollinedo F (2015) Lipid raft-mediated Fas/CD95 apoptotic signaling in leukemic cells and normal leukocytes and therapeutic implications. J. Leukoc. Biol. 98(5):739-759. https://doi.org/10. 1189/jlb.2mr0215-055r

Gallop JL, Walrant A, Cantley LC, Kirschner MW (2013) Phosphoinositides and membrane curvature switch the mode of actin polymerization via selective recruitment of toca-1 and Snx9. Proc. Natl. Acad. Sci. U. S. A. 110(18):7193-7198. https://doi.org/ 10.1073/pnas.1305286110

Gbelcová H, Švéda M, Laubertová L, Varga I, Vítek L, Koláŕ M et al (2013) The effect of simvastatin on lipid droplets accumulation in human embryonic kidney cells and pancreatic cancer cells. Lipids Health Dis. 12(1). https://doi.org/10.1186/1476-511X-12-126

George KS, Wu S (2012) Lipid raft: A floating island of death or survival. Toxicol. Appl. Pharmacol. 259(3):311-319. https://doi.org/10.1016/ j.taap.2012.01.007

Ghandadi M, Valadan R, Mohammadi H, Akhtari J, Khodashenas S, Ashari S (2019) Wnt- $\beta$-catenin Signaling Pathway, the Achilles' Heels of Cancer Multidrug Resistance. Curr. Pharm. Des. 25(39): 4192-4207. https://doi.org/10.2174/1381612825666191112142943

Gibellini F, Smith TK (2010) The Kennedy pathway-De novo synthesis of phosphatidylethanolamine and phosphatidylcholine. IUBMB Life 62(6):414-428. https://doi.org/10.1002/iub.337

Goddard DH, Grossman SL, Newton R, Clark MA, Bomalaski JS (1992) Regulation of synovial cell growth: basic fibroblast growth factor synergizes with interleukin $1 \beta$ stimulating phospholipase A2 enzyme activity, phospholipase A2 activating protein production and release of prostaglandin E2 by rheumatoid arthritis synovial cells in culture. Cytokine 4(5):377-384. https://doi.org/10.1016/10434666(92)90081-2

Gomes L, Sorgine M, Passos CLA, Ferreira C, de Andrade IR, Silva JL et al (2019) Increase in fatty acids and flotillins upon resveratrol treatment of human breast cancer cells. Sci. Rep. 9(1):1-11. https://doi.org/10.1038/s41598-019-50416-5

Gondré-Lewis MC, Petrache HI, Wassif CA, Harries D, Parsegian A, Porter FD, Loh YP (2006) Abnormal sterols in cholesteroldeficiency diseases cause secretory granule malformation and decreased membrane curvature. J. Cell Sci. 119(9):1876-1885. https:// doi.org/10.1242/jcs.02906

Gracià RS, Bezlyepkina N, Knorr RL, Lipowsky R, Dimova R (2010) Effect of cholesterol on the rigidity of saturated and unsaturated membranes: fluctuation and electrodeformation analysis of giant vesicles. Soft Matter 6(7):1472. https://doi.org/10.1039/b920629a

Groux-Degroote S, Guérardel Y, Delannoy P (2017) Gangliosides: Structures, Biosynthesis, Analysis, and Roles in Cancer. Chembiochem 18(13):1146-1154. https://doi.org/10.1002/cbic. 201600705

Guerra FS, Sampaio LS, Konig S, Bonamino M, Rossi MID, Costa ML et al (2016) Membrane cholesterol depletion reduces breast tumor cell migration by a mechanism that involves non-canonical Wnt signaling and IL-10 secretion. Transl. Med. Commun. 1(1):3. https://doi.org/10.1186/s41231-016-0002-4

Guo Y-X, Ma Y-J, Han L, Wang Y-J, Han J-A, Zhu Y (2015) Role of sphingosine 1-phosphate in human pancreatic cancer cells proliferation and migration. Int. J. Clin. Exp. Med. 8(11):20349-20354 Retrieved from http://www.ncbi.nlm.nih.gov/pubmed/26884951

Hammond GRV, Machner MP, Balla T (2014) A novel probe for phosphatidylinositol 4-phosphate reveals multiple pools beyond the Golgi. J. Cell Biol. 205(1):113-126. https://doi.org/10.1083/jcb. 201312072

Han S, Huh J, Kim W, Jeong S, Min DS, Jung Y (2014) Phospholipase D activates HIF-1-VEGF pathway via phosphatidic acid. Exp. Mol. Med. 46(12). https://doi.org/10.1038/emm.2014.86

Hanada K (2010, April) Intracellular trafficking of ceramide by ceramide transfer protein. Proc. Japan Acad. Ser. B Phys. Biol. Sci. https://doi. org/10.2183/pjab.86.426

Hancock JF (2006, June) Lipid rafts: Contentious only from simplistic standpoints. Nat. Rev. Mol. Cell Biol. NIH Public Access. https:// doi.org/10.1038/nrm1925

Haraszti RA, Didiot MC, Sapp E, Leszyk J, Shaffer SA, Rockwell HE et al (2016) High-resolution proteomic and lipidomic analysis of exosomes and microvesicles from different cell sources. J. Extracell. Vesicles 5(1). https://doi.org/10.3402/jev.v5.32570

Hatoum D, Haddadi N, Lin Y, Nassif NT, McGowan EM (2017) Mammalian sphingosine kinase ( $\mathrm{SphK}$ ) isoenzymes and isoform expression: challenges for $\mathrm{SphK}$ as an oncotarget. Oncotarget 8(22). https://doi.org/10.18632/oncotarget.16370

Henriksen JR, Andresen TL, Feldborg LN, Duelund L, Ipsen JH (2010) Understanding detergent effects on lipid membranes: A model study of lysolipids. Biophys. J. 98(10):2199-2205. https://doi.org/10. 1016/j.bpj.2010.01.037

Hess JA, Ross AH, Qiu RG, Symons M, Exton JH (1997) Role of Rho family proteins in phospholipase D activation by growth factors. J. Biol. Chem. 272(3):1615-1620. https://doi.org/10.1074/jbc.272.3. 1615

Hirai H, Natori S, Sekimizu K (1992) Reversal by phosphatidylglycerol and cardiolipin of inhibition of transcription and replication by histones in vitro. Arch. Biochem. Biophys. 298(2):458-463. https:// doi.org/10.1016/0003-9861(92)90435-y

Hishikawa D, Shindou H, Kobayashi S, Nakanishi H, Taguchi R, Shimizu T (2008) Discovery of a lysophospholipid acyltransferase family essential for membrane asymmetry and diversity. Proc. Natl. Acad. Sci. USA 105(8):2830-2835. https://doi.org/10.1073/pnas. 0712245105

Hoejholt KL, Mužić T, Jensen SD, Dalgaard LT, Bilgin M, Nylandsted J et al (2019) Calcium electroporation and electrochemotherapy for cancer treatment: Importance of cell membrane composition investigated by lipidomics, calorimetry and in vitro efficacy. Sci. Rep. 9(1). https://doi.org/10.1038/s41598-019-41188-z

Hoen EN, Cremer T, Gallo RC, Margolis LB (2016, August 16) Extracellular vesicles and viruses: Are they close relatives? Proc. Natl. Acad. Sci. USA. https://doi.org/10.1073/pnas.1605146113

Honsho M, Abe Y, Fujiki Y (2017) Plasmalogen biosynthesis is spatiotemporally regulated by sensing plasmalogens in the inner leaflet of plasma membranes. Sci. Rep. 7. https://doi.org/10.1038/srep43936

Hosain SB, Khiste SK, Uddin MB, Vorubindi V, Ingram C, Zhang S et al (2016) Inhibition of glucosylceramide synthase eliminates the 
oncogenic function of p53 R273H mutant in the epithelialmesenchymal transition and induced pluripotency of colon cancer cells. Oncotarget 7(37):60575-60592. https://doi.org/10.18632/ oncotarget.11169

Hsu FS, Mao Y (2015) The structure of phosphoinositide phosphatases: Insights into substrate specificity and catalysis. Biochim. Biophys. Acta - Mol. Cell Biol. Lipids. Elsevier. https://doi.org/10.1016/j. bbalip.2014.09.015

Hu L, Wang RY, Cai J, Feng D, Yang GZ, Xu QG et al (2016) Overexpression of CHKA contributes to tumor progression and metastasis and predicts poor prognosis in colorectal carcinoma. Oncotarget 7(41):66660-66678. https://doi.org/10.18632/ oncotarget.11433

Hu M, Cheung BMY, Tomlinson B (2012) Safety of statins: An update. Ther. Adv. Drug Saf. SAGE Publ. https://doi.org/10.1177/ 2042098612439884

Huang, F., Wang, K., \& Shen, J. (2020). Lipoprotein-associated phospholipase A2: The story continues. Med. Res. Rev. John Wiley and Sons Inc. https://doi.org/10.1002/med.21597

Huang, W.-C., Chen, C.-L., Lin, Y.-S., \& Lin, C.-F. (2011). Apoptotic Sphingolipid Ceramide in Cancer Therapy. J Lipids, 565316. https:// doi.org/10.1155/2011/565316

Hutchinson S, Battaglia S, Roberg-Larsen H, Hughes T, Thorne J (2018) Cholesterol metabolism and chemo-resistance in breast cancer. Endocr. Abstr. https://doi.org/10.1530/endoabs.59.p111

Hwang S-Y, Kim T-H, Lee H-H (2015) Neutral Sphingomyelinase and Breast Cancer Research. J. Menopausal Med. 21(1):24. https://doi. org/10.6118/jmm.2015.21.1.24

Iuchi K, Ema M, Suzuki M, Yokoyama C, Hisatomi H (2019) Oxidized unsaturated fatty acids induce apoptotic cell death in cultured cells. Mol. Med. Rep. 19(4):2767-2773. https://doi.org/10.3892/mmr. 2019.9940

Jiang XC, Yeang C, Li Z, Chakraborty M, Liu J, Zhang H, Fan Y (2009) Sphingomyelin biosynthesis: Its impact on lipid metabolism and atherosclerosis. Clin. Lipidol. https://doi.org/10.2217/clp.09.49

Kakorin S, Brinkmann U, Neumann E (2005) Cholesterol reduces membrane electroporation and electric deformation of small bilayer vesicles. Biophys. Chem. 117(2):155-171 https://doi.org/10.1016/J. BPC.2005.05.001

Kawasaki Y, Ito A, Withers DA, Taima T, Kakoi N, Saito S, Arai Y (2010) Ganglioside DSGb5, preferred ligand for Siglec-7, inhibits NK cell cytotoxicity against renal cell carcinoma cells. Glycobiology 20(11):1373-1379 https://doi.org/10.1093/glycob/ cwq116

Kindler T, Cornejo MG, Scholl C, Liu J, Leeman DS, Haydu JE et al (2008) K-RasG12D-induced T-cell lymphoblastic lymphoma/ leukemias harbor Notch1 mutations and are sensitive to \{gamma\}secretase inhibitors. Blood 112(8):3373-3382 https://doi.org/10. 1182/blood-2008-03-147587

King HW, Michael MZ, Gleadle JM (2012) Hypoxic enhancement of exosome release by breast cancer cells. BMC Cancer 12(1):421 https://doi.org/10.1186/1471-2407-12-421

Kitajka, K., Martínez, E., Miralles, A., \& Escribá, P. V. (2002). Role of Phosphatidylethanolamine in G Protein-Coupled ReceptorAssociated Signal Transduction (pp. 491-496). https://doi.org/10. 1007/978-1-4615-0193-0 75

Kraveka JM, Li L, Szulc ZM, Bielawski J, Ogretmen B, Hannun YA et al (2007) Involvement of dihydroceramide desaturase in cell cycle progression in human neuroblastoma cells. J. Biol. Chem. 282(23):16718-16728. https://doi.org/10.1074/jbc.M700647200

Krawitz PM, Murakami Y, Rieß A, Hietala M, Krüger U, Zhu N et al (2013) PGAP2 mutations, affecting the GPI-anchor-synthesis pathway, cause hyperphosphatasia with mental retardation syndrome. Am. J. Hum. Genet. 92(4):584-589. https://doi.org/10.1016/j.ajhg. 2013.03.011
Krengel U, Bousquet PA (2014) Molecular recognition of gangliosides and their potential for cancer immunotherapies. Front. Immunol. Frontiers Research Foundation. https://doi.org/10.3389/fimmu. 2014.00325

Kuge O, Nishijima M (1997, September 4) Phosphatidylserine synthase I and II of mammalian cells. Biochim. Biophys. Acta - Lipids Lipid Metab. https://doi.org/10.1016/S0005-2760(97)00137-9

Kuge O, Saito K, Nishijima M (1997) Cloning of a Chinese hamster ovary (CHO) cDNA encoding phosphatidylserine synthase (PSS) II, overexpression of which suppresses the phosphatidylserine biosynthetic defect of a PSS I-lacking mutant of CHO-K1 cells. J. Biol. Chem. 272(31):19133-19139 https://doi.org/10.1074/jbc.272.31. 19133

Kurrasch-Orbaugh DM, Watts VALJ, Barker EL, Nichols DE (2003) Phospholipase C and Phospholipase A2 Signaling Pathways Have Different Receptor Reserves. J Pharmacol Exp Ther. 304(1):229 237. https://doi.org/10.1124/jpet.102.042184.nature

Lane DJR, Bae DH, Merlot AM, Sahni S, Richardson DR (2015, March 31) Duodenal cytochrome b (DCYTB) in Iron metabolism: An update on function and regulation. Nutrients. MDPI AG. https:// doi.org/10.3390/nu7042274

Lang Z, Guerrera M, Li R, Ladisch S (2001) Ganglioside GD1a enhances VEGF-induced endothelial cell proliferation and migration. Biochem. Biophys. Res. Commun. 282(4):1031-1037. https://doi. org/10.1006/bbrc.2001.4630

Lankry D, Rovis TL, Jonjic S, Mandelboim O (2013) The interaction between CD300a and phosphatidylserine inhibits tumor cell killing by NK cells. Eur. J. Immunol. 43(8):2151-2161. https://doi.org/10. 1002/eji.201343433

Lee CH, Kim HK, Jeong JS, Lee YD, Jin ZW, Im SY, Lee HK (2015) Mechanism of glutamine inhibition of cytosolic phospholipase a2 (cPLA2): Evidence of physical interaction between glutamineInduced mitogen-activated protein kinase phosphatase- 1 and cPLA2. Clin. Exp. Immunol. 180(3):571-580. https://doi.org/10. 1111/cei.12585

Lee S, Hirt H, Lee Y (2001) Phosphatidic acid activates a woundactivated MAPK in Glycine max. Plant J. 26(5):479-486. https:// doi.org/10.1046/j.1365-313x.2001.01037.x

Leung YM, Xion Y, Ou YJ, Kwan CY (1998) Perturbation by lysophosphatidylcholine of membrane permeability in cultured vascular smooth muscle and endothelial cells. Life Sci. 63(11):965973. https://doi.org/10.1016/s0024-3205(98)00354-3

Li J, Condello S, Thomes-Pepin J, Ma X, Xia Y, Hurley TD et al (2017) Lipid Desaturation Is a Metabolic Marker and Therapeutic Target of Ovarian Cancer Stem Cells. Cell Stem Cell 20(3):303-314.e5. https://doi.org/10.1016/j.stem.2016.11.004

Li M, Zhang Z, Yuan J, Zhang Y, Jin X (2014) Altered glutamate cysteine ligase expression and activity in renal cell carcinoma. Biomed. Reports 2(6):831-834. https://doi.org/10.3892/br.2014.359

Li X, Wang X, Zhang X, Zhao M, Tsang WL, Zhang Y et al (2013) Genetically encoded fluorescent probe to visualize intracellular phosphatidylinositol 3,5-bisphosphate localization and dynamics. Proc. Natl. Acad. Sci. U. S. A. 110(52):21165-21170. https://doi. org/10.1073/pnas.1311864110

Li YC, Park MJ, Ye SK, Kim CW, Kim YN (2006) Elevated levels of cholesterol-rich lipid rafts in cancer cells are correlated with apoptosis sensitivity induced by cholesterol-depleting agents. Am. J. Pathol. 168(4):1107-1118. https://doi.org/10.2353/ajpath.2006. 050959

Liscovitch M, Czarny M, Fiucci G, Tang X (2000, February 1) Phospholipase D: Molecular and cell biology of a novel gene family. Biochem. J. Portland Press Ltd. https://doi.org/10.1042/0264-6021: 3450401

Liu L, Choudhary V, Toulmay A, Prinz WA (2017a) An inducible ERGolgi tether facilitates ceramide transport to alleviate lipotoxicity. J. Cell Biol. 216(1):131-147. https://doi.org/10.1083/jcb.201606059 
Liu S, Sheng R, Jung JH, Wang L, Stec E, O'Connor MJ et al (2017b) Orthogonal lipid sensors identify transbilayer asymmetry of plasma membrane cholesterol. Nat. Chem. Biol. 13(3):268-274. https://doi. org/10.1038/nchembio.2268

Liu Y-Y, Gupta V, Patwardhan GA, Bhinge K, Zhao Y, Bao J et al (2010) Glucosylceramide synthase upregulates MDR1 expression in the regulation of cancer drug resistance through $\mathrm{cSrc}$ and beta-catenin signaling. Mol. Cancer 9:145. https://doi.org/10.1186/1476-4598-9145

Liu, Y. Y., Hill, R. A., \& Li, Y. T. (2013). Ceramide Glycosylation Catalyzed by Glucosylceramide Synthase and Cancer Drug Resistance. In Advances in Cancer Research (Vol. 117, pp. 5989). Academic Press Inc. https://doi.org/10.1016/B978-0-12394274-6.00003-0

Lladó V, López DJ, Ibarguren M, Alonso M, Soriano JB, Escribá PV, Busquets X (2014) Regulation of the cancer cell membrane lipid composition by NaCHOleate: effects on cell signaling and therapeutical relevance in glioma. Biochim. Biophys. Acta 1838(6):1619-1627. https://doi.org/10.1016/j.bbamem.2014.01. 027

Long J, Zhang C-J, Zhu N, Du K, Yin Y-F, Tan X et al (2018) Lipid metabolism and carcinogenesis, cancer development. Am. J. Cancer Res. 8(5):778-791 Retrieved from http://www.ncbi.nlm.nih.gov/ pubmed/29888102

Lucas L, Penalva V, Ramírez de Molina A, Del Peso L, Lacal JC (2002) Modulation of phospholipase D by Ras proteins mediated by its effectors Ral-GDS, PI3K and Raf-1. Int. J. Oncol. 21(3):477-485 Retrieved from http://www.ncbi.nlm.nih.gov/pubmed/12168089

Luo X, Zhao X, Cheng C, Li N, Liu Y, Cao Y (2018) The implications of signaling lipids in cancer metastasis. Exp. Mol. Med. Nature Publishing Group. https://doi.org/10.1038/s12276-018-0150-x

Manara MC, Nicoletti G, Zambelli D, Ventura S, Guerzoni C, Landuzzi L et al (2010) NVP-BEZ235 as a new therapeutic option for sarcomas. Clin. Cancer Res. 16(2):530-540. https://doi.org/10.1158/10780432.CCR-09-0816

Manna, P., \& Jain, S. K. (2015). Phosphatidylinositol-3,4,5-triphosphate and cellular signaling: Implications for obesity and diabetes. Cell. Physiol. Biochem. S. Karger AG. https://doi.org/10.1159/ 000373949

Mariggiò S, Bavec A, Natale E, Zizza P, Salmona M, Corda D, Di Girolamo M (2006) Galpha13 mediates activation of the cytosolic phospholipase A2alpha through fine regulation of ERK phosphorylation. Cell. Signal. 18(12):2200-2208 https://doi.org/10.1016/j. cellsig.2006.05.003

Martirosyan A, Clendening JW, Goard CA, Penn LZ (2010) Lovastatin induces apoptosis of ovarian cancer cells and synergizes with doxorubicin: Potential therapeutic relevance. BMC Cancer 10. https:// doi.org/10.1186/1471-2407-10-103

Mason P, Liang B, Li L, Fremgen T, Murphy E, Quinn A et al (2012) SCD1 inhibition causes cancer cell death by depleting monounsaturated fatty acids. PLoS One 7(3):e33823. https://doi.org/10. 1371/journal.pone. 0033823

Massaro C, Thomas J, Phanstiel O IV (2017) Investigation of Polyamine Metabolism and Homeostasis in Pancreatic Cancers. Med. Sci. 5(4): 32. https://doi.org/10.3390/medsci5040032

Matsubara T, Ikeda M, Kiso Y, Sakuma M, Yoshino KI, Sakane F et al (2012) c-Abl tyrosine kinase regulates serum-induced nuclear export of diacylglycerol kinase $\alpha$ by Phosphorylation at Tyr-218. J. Biol. Chem. 287(8):5507-5517. https://doi.org/10.1074/jbc.M111. 296897

Matsubara T, Shirai Y, Miyasaka K, Murakami T, Yamaguchi Y, Ueyama $T$ et al (2006) Nuclear transportation of diacylglycerol kinase $\gamma$ and its possible function in the nucleus. J. Biol. Chem. 281(10):61526164. https://doi.org/10.1074/jbc.M509873200
Mccartney AJ, Zhang Y, Weisman LS (2014) Phosphatidylinositol 3,5bisphosphate: Low abundance, high significance. BioEssays. https://doi.org/10.1002/bies.201300012

McLaughlin S, Murray D (2005, December 1) Plasma membrane phosphoinositide organization by protein electrostatics. Nature. Nature Publishing Group. https://doi.org/10.1038/nature04398

Melnykovych G, Haug JS, Goldner CM (1992) Growth inhibition of leukemia cell line CEM-C1 by farnesol: Effects of phosphatidylcholine and diacylglycerol. Biochem. Biophys. Res. Commun. 186(1): 543-548. https://doi.org/10.1016/S0006-291X(05)80842-3

Menon AK, Eppinger M, Mayor S, Schwarz RT (1993) Phosphatidylethanolamine is the donor of the terminal phosphoethanolamine group in trypanosome glycosylphosphatidylinositols. EMBO J. 12(5):1907-1914. https:// doi.org/10.1002/j.1460-2075.1993.tb05839.x

Milburn CC, Deak M, Kelly SM, Price NC, Alessi DR, Van Aalten DMF (2003) Binding of phosphatidylinositol 3,4,5-trisphosphate to the pleckstrin homology domain of protein kinase B induces a conformational change. Biochem. J. 375(Pt 3):531-538. https://doi.org/10. 1042/BJ20031229

Mo, H., Jeter, R., Bachmann, A., Yount, S. T., Shen, C. L., \& Yeganehjoo, H. (2019). The potential of isoprenoids in adjuvant cancer therapy to reduce adverse effects of statins. Front. Pharmacol. Frontiers Media S.A. https://doi.org/10.3389/fphar.2018.01515

Modok S, Heyward C, Callaghan R (2004) P-glycoprotein retains function when reconstituted into a sphingolipid- and cholesterol-rich environment. J. Lipid Res. 45(10):1910-1918. https://doi.org/10. 1194/jlr.M400220-JLR200

Mollinedo, F., \& Gajate, C. (2020). Lipid rafts as signaling hubs in cancer cell survival/death and invasion: implications in tumor progression and therapy. Retrieved from www.jlr.org

Moro K, Nagahashi M, Gabriel E, Takabe K, Wakai T (2019) Clinical application of ceramide in cancer treatment. Breast Cancer. Springer Tokyo. https://doi.org/10.1007/s12282-019-00953-8

Muftuoglu Y, Xue Y, Gao X, Wu D, Ha Y (2016) Mechanism of substrate specificity of phosphatidylinositol phosphate kinases. Proc. Natl. Acad. Sci. U. S. A. 113(31):8711-8716 https://doi.org/10.1073/ pnas. 1522112113

Mukherjee A, Kenny HA, Lengyel E (2017, March 2) Unsaturated Fatty Acids Maintain Cancer Cell Stemness. Cell Stem Cell. Cell Press. https://doi.org/10.1016/j.stem.2017.02.008

Mullen TD, Obeid LM (2012) Ceramide and apoptosis: exploring the enigmatic connections between sphingolipid metabolism and programmed cell death. Anticancer. Agents Med. Chem. 12(4):340 363 Retrieved from http://www.ncbi.nlm.nih.gov/pubmed/ 21707511

Murakami M, Sato H, Miki Y, Yamamoto K, Taketomi Y (2015, July 1) A new era of secreted phospholipase A2. J. Lipid Res. Am Soc Biochem Mole Biol Inc. https://doi.org/10.1194/jlr.R058123

Murray NR, Fields AP (1998) Phosphatidylglycerol is a physiologic activator of nuclear protein kinase C. J. Biol. Chem. 273(19):11514 11520. https://doi.org/10.1074/jbc.273.19.11514

Nagarajan SR, Paul-Heng M, Krycer JR, Fazakerley DJ, Sharland AF, Hoy XAJ (2019) Lipid and glucose metabolism in hepatocyte cell lines and primary mouse hepatocytes: A comprehensive resource for in vitro studies of hepatic metabolism. Am. J. Physiol. - Endocrinol. Metab. 316(4):E578-E589. https://doi.org/10.1152/ajpendo.00365. 2018

Nascimbeni AC, Codogno P, Morel E (2017) Phosphatidylinositol-3phosphate in the regulation of autophagy membrane dynamics. FEBS J. Blackwell Publishing Ltd. https://doi.org/10.1111/febs. 13987

Nordström T, Clements M, Karlsson R, Adolfsson J, Grönberg H (2015) The risk of prostate cancer for men on aspirin, statin or antidiabetic medications. Eur. J. Cancer 51(6):725-733. https://doi.org/10.1016/ j.ejca.2015.02.003 
Ogretmen B (2017) Sphingolipid metabolism in cancer signalling and therapy. Nat. Rev. Cancer. Nature Publishing Group. https://doi. org/10.1038/nrc.2017.96

Ollila S, Hyvönen MT, Vattulainen I (2007) Polyunsaturation in lipid membranes: Dynamic properties and lateral pressure profiles. J. Phys. Chem. B 111(12):3139-3150. https://doi.org/10.1021/ jp065424f

Oude Weernink PA, Han L, Jakobs KH, Schmidt M (2007) Dynamic phospholipid signaling by $\mathrm{G}$ protein-coupled receptors. Biochim. Biophys. Acta - Biomembr. Elsevier. https://doi.org/10.1016/j. bbamem.2006.09.012

Pakiet A, Kobiela J, Stepnowski P, Sledzinski T, Mika A (2019) Changes in lipids composition and metabolism in colorectal cancer: A review. Lipids Health Dis. BioMed Central Ltd. https://doi.org/10.1186/ s12944-019-0977-8

Panneer Selvam S, De Palma RM, Oaks JJ, Oleinik N, Peterson YK, Stahelin RV et al (2015) Binding of the sphingolipid S1P to hTERT stabilizes telomerase at the nuclear periphery by allosterically mimicking protein phosphorylation. Sci. Signal. 8(381):ra58 https://doi.org/10.1126/scisignal.aaa4998

Papageorgis P, Cheng K, Ozturk S, Gong Y, Lambert AW, Abdolmaleky $\mathrm{HM}$ et al (2011) Smad4 inactivation promotes malignancy and drug resistance of colon cancer. Cancer Res. 71(3):998-1008. https://doi. org/10.1158/0008-5472.CAN-09-3269

Papandreou I, Goliasova T, Denko NC (2011) Anticancer drugs that target metabolism: Is dichloroacetate the new paradigm? Int. J. Cancer. John Wiley \& Sons, Ltd. https://doi.org/10.1002/ijc.25728

Parham KA, Zebol JR, Tooley KL, Sun WY, Moldenhauer LM, Cockshell MP et al (2015) Sphingosine 1-phosphate is a ligand for peroxisome proliferator-activated receptor- $\gamma$ that regulates neoangiogenesis. FASEB J. 29(9):3638-3653. https://doi.org/10. 1096/fj.14-261289

Park ES, Choi S, Shin B, Yu J, Yu J, Hwang JM et al (2015) Tumor necrosis factor (TNF) receptor-associated factor (TRAF)-interacting protein (TRIP) negatively regulates the TRAF2 ubiquitin-dependent pathway by suppressing the TRAF2-sphingosine 1-phosphate (S1P) interaction. J. Biol. Chem. 290(15):9660-9673 https://doi.org/10. 1074/jbc.M114.609685

Park K, Elias PM, Shin K-O, Lee Y-M, Hupe M, Borkowski AW et al (2013) A Novel Role of a Lipid Species, Sphingosine-1-Phosphate, in Epithelial Innate Immunity. Mol. Cell. Biol. 33(4):752-762. https://doi.org/10.1128/mcb.01103-12

Pascual G, Avgustinova A, Mejetta S, Martín M, Castellanos A, Attolini CSO et al (2017) Targeting metastasis-initiating cells through the fatty acid receptor CD36. Nature 541(7635):41-45. https://doi.org/ 10.1038/nature20791

Pasmant E, Vidaud D, Ballerini P (2015) RAS MAPK inhibitors deregulation in leukemia. Oncoscience. Impact Journals LLC. https://doi. org/10.18632/oncoscience. 274

Patel D, Witt SN (2017) Ethanolamine and. Partners in Health and Disease. Oxid. Med. Cell. Longev. Hindawi Limited, Phosphatidylethanolamine. https://doi.org/10.1155/2017/4829180

Payne AW, Pant DK, Pan T-C, Chodosh LA (2014) Ceramide kinase promotes tumor cell survival and mammary tumor recurrence. Cancer Res. 74(21):6352-6363. https://doi.org/10.1158/00085472.CAN-14-1292

Peck B, Schug ZT, Zhang Q, Dankworth B, Jones DT, Smethurst E et al (2016) Inhibition of fatty acid desaturation is detrimental to cancer cell survival in metabolically compromised environments. Cancer Metab. 4(1):6. https://doi.org/10.1186/s40170-016-0146-8

Peetla C, Vijayaraghavalu S, Labhasetwar V (2013) Biophysics of cell membrane lipids in cancer drug resistance: Implications for drug transport and drug delivery with nanoparticles. Adv. Drug Deliv. Rev. NIH Public Access. https://doi.org/10.1016/j.addr.2013.09.004

Peng Y, He G, Tang D, Xiong L, Wen Y, Miao X et al (2017) Lovastatin inhibits Csancer stem cells and Sensitizes to chemo- and photodynamic therapy in Nasopharyngeal carcinoma. J. Cancer 8(9):1655-1664. https://doi.org/10.7150/jca.19100

Perrotti F, Rosa C, Cicalini I, Sacchetta P, Del Boccio P, Genovesi D, Pieragostino D (2016, December 1) Advances in lipidomics for cancer biomarkers discovery. Int. J. Mol. Sci. MDPI AG. https:// doi.org/10.3390/ijms 17121992

Pike LJ (2003) Lipid rafts: bringing order to chaos. J. Lipid Res. 44(4): 655-667. https://doi.org/10.1194/jlr.R200021-JLR200

Pike LJ (2004) Lipid rafts: heterogeneity on the high seas. Biochem. J. 378(Pt 2):281-292. https://doi.org/10.1042/BJ20031672

Pitcher JA, Fredericks ZL, Stone WC, Premont RT, Stoffel RH, Koch WJ, Lefkowitz RJ (1996) Phosphatidylinositol 4,5-bisphosphate (PIP2)enhanced G protein-coupled receptor kinase (GRK) activity. Location, structure, and regulation of the PIP2 binding site distinguishes the GRK subfamilies. J. Biol. Chem. 271(40):2490724913. https://doi.org/10.1074/jbc.271.40.24907

Plattner R, Kadlec L, DeMali KA, Kazlauskas A, Pendergast AM (1999) $\mathrm{c}-\mathrm{Abl}$ is activated by growth factors and Src family kinases and has a role in the cellular response to PDGF. Genes Dev. 13(18):2400 2411. https://doi.org/10.1101/gad.13.18.2400

Podo, F., Paris, L., Cecchetti, S., Spadaro, F., Abalsamo, L., Ramoni, C., ... Iorio, E. (2016). Activation of phosphatidylcholinespecific phospholipase $\mathrm{C}$ in breast and ovarian cancer: Impact on mrs-detected choline metabolic profile and perspectives for targeted therapy. Front. Oncol., 6. https://doi.org/10.3389/fonc.2016.00171

Poli A, Zaurito AE, Abdul-Hamid S, Fiume R, Faenza I, Divecha N (2019) Phosphatidylinositol 5 phosphate (Pi5p): From behind the scenes to the front (nuclear) stage. Int. J. Mol. Sci. MDPI AG. https://doi.org/10.3390/ijms20092080

Porter NA, Caldwell SE, Mills KA (1995, April) Mechanisms of free radical oxidation of unsaturated lipids. Lipids. Springer-Verlag. https://doi.org/10.1007/BF02536034

Pradas, I., Huynh, K., Cabré, R., Ayala, V., Meikle, P. J., Jové, M., \& Pamplona, R. (2018). Lipidomics reveals a tissue-specific fingerprint. Front. Physiol., 9(AUG). https://doi.org/10.3389/fphys.2018. 01165

Preetha A, Banerjee R, Huilgol N (2005) Surface activity, lipid profiles and their implications in cervical cancer. J. Cancer Res. Ther. 1(3): 180. https://doi.org/10.4103/0973-1482.19600

Preininger AM, Henage LG, Oldham WM, Yoon EJ, Hamm HE, Brown HA (2006) Direct modulation of phospholipase D activity by Gbetagamma. Mol. Pharmacol. 70(1):311-318. https://doi.org/10. 1124/mol.105.021451

Pukel CS, Lloyd KO, Travassos LR, Dippold WG, Oettgen HF, Old LJ (1982) GD3, a prominent ganglioside of human melanoma. Detection and characterisation by mouse monoclonal antibody. J. Exp. Med. 155(4):1133-1147. https://doi.org/10.1084/jem.155.4. 1133

Purow B (2015) Molecular pathways: Targeting diacylglycerol kinase alpha in cancer. Clin. Cancer Res. 21(22):5008-5012. https://doi. org/10.1158/1078-0432.CCR-15-0413

Pustylnikov S, Costabile F, Beghi S, Facciabene A (2018, December 1) Targeting mitochondria in cancer: current concepts and immunotherapy approaches. Transl. Res. Mosby Inc. https://doi.org/10. 1016/j.trsl.2018.07.013

Putta P, Rankenberg J, Korver RA, van Wijk R, Munnik T, Testerink C, Kooijman EE (2016) Phosphatidic acid binding proteins display differential binding as a function of membrane curvature stress and chemical properties. Biochim. Biophys. Acta - Biomembr. 1858(11):2709-2716. https://doi.org/10.1016/j.bbamem.2016.07. 014

Rajala, R. V. S., \& Anderson, R. E. (2010, September). Focus on Molecules: Phosphatidylinositol-4,5-bisphosphate (PIP2). Exp. Eye Res. NIH Public Access. https://doi.org/10.1016/j.exer.2010. 05.001 
Reynaert H, De Coninck A, Neven AM, Van Camp B, Schots R (1992) Chemotherapy-induced acral erythema and acute graft-versus-host disease after allogeneic bone marrow transplantation. Bone Marrow Transplant. 10(2):185-187 Retrieved from http://www.ncbi.nlm. nih.gov/pubmed/1388082

Rhee SG (2001) Regulation of Phosphoinositide-Specific Phospholipase C. Annu. Rev. Biochem. 70(1):281-312. https://doi.org/10.1146/ annurev.biochem.70.1.281

Ribas V, García-Ruiz C, Fernández-Checa JC (2016) Mitochondria, cholesterol and cancer cell metabolism. Clin. Transl. Med. 5(1). https:// doi.org/10.1186/s40169-016-0106-5

Rivel T, Ramseyer C, Yesylevskyy S (2019) The asymmetry of plasma membranes and their cholesterol content influence the uptake of cisplatin. Sci. Rep. 9(1):1-14. https://doi.org/10.1038/s41598-01941903-w

Rockenfeller P, Koska M, Pietrocola F, Minois N, Knittelfelder O, Sica V et al (2015) Phosphatidylethanolamine positively regulates autophagy and longevity. Cell Death Differ. 22(3):499-508. https://doi.org/ 10.1038/cdd.2014.219

Rodwell, V. W., Bender, D. A., Botham, K. M., Kennelly, P. J., \& Weil, P. A. (2015). Harper's illustrated biochemistry. Retrieved from https:// www.worldcat.org/title/harpers-illustrated-biochemistry/oclc/ 900011174

Rog T, Koivuniemi A (2016) The biophysical properties of ethanolamine plasmalogens revealed by atomistic molecular dynamics simulations. Biochim. Biophys. Acta - Biomembr. 1858(1):97-103. https://doi.org/10.1016/j.bbamem.2015.10.023

Rothman JE, Lenard J (1977) Membrane asymmetry. Science (80) 195(4280):743-753. https://doi.org/10.1126/science.402030

Sands JA, Lowlicht RA (1976) Temporal origin of viral phospholipids of the enveloped bacteriophage phi 6. Can. J. Microbiol. 22(2):154 158. https://doi.org/10.1139/m76-021

Santana P, Peña LA, Haimovitz-Friedman A, Martin S, Green D, McLoughlin M et al (1996) Acid sphingomyelinase-deficient human lymphoblasts and mice are defective in radiation-induced apoptosis. Cell 86(2):189-199. https://doi.org/10.1016/S0092-8674(00) 80091-4

Segawa K, Nagata S (2015) An Apoptotic "Eat Me" Signal: Phosphatidylserine Exposure. Trends Cell Biol. Elsevier Ltd. https://doi.org/10.1016/j.tcb.2015.08.003

Sezgin E, Levental I, Mayor S, Eggeling C (2017) The mystery of membrane organization: composition, regulation and roles of lipid rafts. Nat. Rev. Mol. Cell Biol. 18(6):361-374. https://doi.org/10.1038/ nrm.2017.16

Sharma A, Bandyopadhayaya S, Chowdhury K, Sharma T, Maheshwari R, Das A et al (2019) Metformin exhibited anticancer activity by lowering cellular cholesterol content in breast cancer cells. PLoS One 14(1):e0209435. https://doi.org/10.1371/journal.pone.0209435

Sharma B, Kanwar SS (2018) Phosphatidylserine: A cancer cell targeting biomarker. Semin. Cancer Biol. Academic Press. https://doi.org/10. 1016/j.semcancer.2017.08.012

Shepherd J, Blauw GJ, Murphy MB, Bollen ELEM, Buckley BM, Cobbe SM et al (2002) Pravastatin in elderly individuals at risk of vascular disease (PROSPER): A randomised controlled trial. Lancet 360(9346):1623-1630. https://doi.org/10.1016/S0140-6736(02) $11600-\mathrm{X}$

Shindou, H., Hishikawa, D., Harayama, T., Yuki, K., \& Shimizu, T. (2009). Recent progress on acyl CoA: Lysophospholipid acyltransferase research. J. Lipid Res. J Lipid Res. https://doi.org/10.1194/jlr. R800035-JLR200

Shlomovitz I, Speir M, Gerlic M (2019) Flipping the dogma Phosphatidylserine in non-apoptotic cell death. Cell Commun. Signal. BioMed Central Ltd. https://doi.org/10.1186/s12964-0190437-0

Shyu P, Ng BSH, Ho N, Chaw R, Seah YL, Marvalim C, Thibault G (2019) Membrane phospholipid alteration causes chronic ER stress through early degradation of homeostatic ER-resident proteins. Sci. Rep. 9(1). https://doi.org/10.1038/s41598-019-45020-6

Shyu P, Wong XFA, Crasta K, Thibault G (2018, September 19) Dropping in on lipid droplets: Insights into cellular stress and cancer. Biosci. Rep. Portland Press Ltd. https://doi.org/10.1042/ BSR20180764

Signorell A, Jelk J, Rauch M, Bütikofer P (2008) Phosphatidylethanolamine is the precursor of the ethanolamine phosphoglycerol moiety bound to eukaryotic elongation factor $1 \mathrm{~A}$. J. Biol. Chem. 283(29):20320-20329. https://doi.org/10.1074/jbc. M802430200

Simons K, Ehehalt R (2002) Cholesterol, lipid rafts, and disease. J. Clin. Invest. 110(5):597-603. https://doi.org/10.1172/JCI16390

Siso-Nadal F, Fox JJ, Laporte SA, Hébert TE, Swain PS (2009) Crosstalk between signaling pathways can generate robust oscillations in calcium and cAMP. PLoS One 4(10):e7189. https://doi.org/10.1371/ journal.pone.0007189

Slotte JP, Ramstedt B (2007) The functional role of sphingomyelin in cell membranes. Eur J Lipid Sci Technol 109:977-981. https://doi.org/ 10.1002/ejlt.200700024

Sola-Leyva A, López-Cara LC, Ríos-Marco P, Ríos A, Marco C, Carrasco-Jiménez MP (2019) Choline kinase inhibitors EB-3D and EB-3P interferes with lipid homeostasis in HepG2 cells. Sci. Rep. 9(1):1-13. https://doi.org/10.1038/s41598-019-40885-z

Soler A, Figueiredo AM, Castel P, Martin L, Monelli E, Angulo-Urarte A et al (2016) Therapeutic Benefit of Selective Inhibition of $p 110 \alpha$ PI3-Kinase in Pancreatic Neuroendocrine Tumors. Clin. Cancer Res. 22(23):5805-5817. https://doi.org/10.1158/1078-0432.CCR15-3051

Srivatsav AT, Mishra M, Kapoor S (2018) Small-Molecule Modulation of Lipid-Dependent Cellular Processes Against Cancer: Fats on the Gunpoint. Biomed Res. Int. https://doi.org/10.1155/2018/6437371

Stellacci E, Di Noia A, Di Baldassarre A, Migliaccio G, Battistini A, Migliaccio AR (2009) Interaction between the glucocorticoid and erythropoietin receptors in human erythroid cells. Exp. Hematol. 37(5):559-572. https://doi.org/10.1016/j.exphem.2009.02.005

Stith BJ (2015, May 15) Phospholipase C and D regulation of Src, calcium release and membrane fusion during Xenopus laevis development. Dev. Biol. Academic Press Inc. https://doi.org/10.1016/j. ydbio.2015.02.020

Stone SJ, Vance JE (2000) Phosphatidylserine synthase-1 and -2 are localized to mitochondria-associated membranes. J. Biol. Chem. 275(44):34534-34540. https://doi.org/10.1074/jbc.M002865200

Stoppa G, Rumiato E, Saggioro D (2012) Ras signaling contributes to survival of human T-cell leukemia/lymphoma virus type 1 (HTLV1) Tax-positive T-cells. Apoptosis 17(3):219-228. https://doi.org/ 10.1007/s10495-011-0676-z

Supattapone S (2012) Phosphatidylethanolamine as a prion cofactor: Potential implications for disease pathogenesis. Prion. https://doi. org/10.4161/pri.21826

Tan LTH, Chan KG, Pusparajah P, Lee WL, Chuah LH, Khan TM et al (2017) Targeting membrane lipid a potential cancer cure? Front. Pharmacol. 8(12):1-6. https://doi.org/10.3389/fphar.2017.00012

Thapa N, Tan X, Choi S, Lambert PF, Rapraeger AC, Anderson RA (2016) The Hidden Conundrum of Phosphoinositide Signaling in Cancer. Trends in Cancer. Cell Press. https://doi.org/10.1016/j. trecan.2016.05.009

Tsuchida J, Nagahashi M, Takabe K, Wakai T (2017) Clinical Impact of Sphingosine-1-Phosphate in Breast Cancer. Mediators Inflamm. Hindawi Limited. https://doi.org/10.1155/2017/2076239

Vallianou N, Kostantinou A, Kougias M, Kazazis C (2014) Statins and Cancer. Anticancer. Agents Med. Chem. 14(5):706-712. https://doi. org/10.2174/1871520613666131129105035

Van Blitterswijk WJ, Van Der Luit AH, Veldman RJ, Verheij M, Borst J (2003) Ceramide: Second messenger or modulator of membrane structure and dynamics? Biochem. J. https://doi.org/10.1042/BJ20021528 
Van Meer G (2005) Cellular lipidomics. EMBO J. 24(18):3159-3165. https://doi.org/10.1038/sj.emboj.7600798

Van Meer G, Voelker DR, Feigenson GW (2008) Membrane lipids: Where they are and how they behave. Nat. Rev. Mol. Cell Biol. https://doi.org/10.1038/nrm2330

Vance JE, Steenbergen R (2005) Metabolism and functions of phosphatidylserine. Prog. Lipid Res. 44(4):207-234. https://doi. org/10.1016/j.plipres.2005.05.001

Wang H, Giuliano AE, Cabot MC (2002) Enhanced de novo ceramide generation through activation of serine palmitoyltransferase by the P-glycoprotein antagonist SDZ PSC 833 in breast cancer cells. Mol. Cancer Ther. 1(9):719-726 Retrieved from http://www.ncbi.nlm. nih.gov/pubmed/12479368

Wang R, Bi J, Ampah KK, Ba X, Liu W, Zeng X (2013) Lipid rafts control humasn melanoma cell migration by regulating focal adhesion disassembly. Biochim. Biophys. Acta - Mol. Cell Res. 1833(12):3195-3205. https://doi.org/10.1016/j.bbamcr.2013.09.007

Wang X, Li N, Liu B, Sun H, Chen T, Li H et al (2004) A novel human phosphatidylethanolamine-binding protein resists tumor necrosis factor $\alpha$-induced apoptosis by inhibiting mitogen-activated protein kinase pathway activation and phosphatidylethanolamine externalization. J. Biol. Chem. 279(44):45855-45864. https://doi.org/10. 1074/jbc.M405147200

Watters RJ, Wang H-G, Sung S-S, Loughran TP, Liu X, Liu X (2011) Targeting sphingosine-1-phosphate receptors in cancer. Anticancer. Agents Med. Chem. 11(9):810-817 Retrieved from http:// www.ncbi.nlm.nih.gov/pubmed/21707490\%0Ahttp:// www.ncbi.nlm.nih.gov/pubmed/21707490

Weiser BP, Salari R, Eckenhoff RG, Brannigan G (2014) Computational investigation of cholesterol binding sites on mitochondrial VDAC. J. Phys. Chem. B 118(33):9852-9860. https://doi.org/10.1021/ jp504516a

White-Gilbertson S, Mullen T, Senkal C, Lu P, Ogretmen B, Obeid L, Voelkel-Johnson C (2009) Ceramide synthase 6 modulates TRAIL sensitivity and nuclear translocation of active caspase-3 in colon cancer cells. Oncogene 28(8):1132-1141. https://doi.org/10.1038/ onc. 2008.468

Wirtz KW, Van Kessel WS, Kamp HH, Demel RA (1976) The proteinmediated transfer of phosphatidylcholine between membranes. The effect of membrane lipid composition and ionic composition of the medium. Eur. J. Biochem. 61(2):515-523. https://doi.org/10.1111/j. 1432-1033.1976.tb10046.x

Wnętrzak A, Łątka K, Makyła-Juzak K, Zemla J, Dynarowicz-Łątka P (2015) The influence of an antitumor lipid - erucylphosphocholine on artificial lipid raft system modeled as Langmuir monolayer. Mol. Membr. Biol. 32(5-8):189-197. https://doi.org/10.3109/09687688. 2015.1125537

Woodcock J (2006) Sphingosine and ceramide signalling in apoptosis. IUBMB Life 58(8):462-466. https://doi.org/10.1080/ 15216540600871118

Wu CY, Lin MW, Wu DC, Huang YB, Huang HT, Chen CL (2014) The role of phosphoinositide-regulated actin reorganization in chemotaxis and cell migration. Br. J. Pharmacol. 171(24):5541-5554. https://doi.org/10.1111/bph.12777

Wu T, Levine SJ, Lawrence MG, Logun C, Angus CW, Shelhamer JH (1994) Interferon- $\gamma$ induces the synthesis and activation of cytosolic phospholipase A2. J. Clin. Invest. 93(2):571-577. https://doi.org/10. 1172/JCI117009

Xie G, Wang Z, Chen Y, Zhang S, Feng L, Meng F, Yu Z (2017) Dual blocking of PI3K and mTOR signaling by NVP-BEZ235 inhibits proliferation in cervical carcinoma cells and enhances therapeutic response. Cancer Lett. 388:12-20. https://oi.org/10.1016/j.canlet. 2016.11.024

Xu T, Ding W, Ji X, Ao X, Liu Y, Yu W, Wang J (2019) Molecular mechanisms of ferroptosis and its role in cancer therapy. J. Cell. Mol. Med. Blackwell Publishing Inc. https://doi.org/10.1111/jcmm.14511
$\mathrm{Xu}$, Y. (2018). Lysophospholipid signaling in the epithelial ovarian cancer tumor microenvironment. Cancers (Basel). MDPI AG. https:// doi.org/10.3390/cancers 10070227

Yan Lim, J., \& Yee Kwan, H. (2018). Roles of Lipids in Cancer. In Lipid Metabolism [Working Title]. IntechOpen. https://doi.org/10.5772/ intechopen. 80788

Yang F, Chen GX (2018) Production of extracellular lysophosphatidic acid in the regulation of adipocyte functions and liver fibrosis. World J. Gastroenterol. 24(36):4132-4151. https://doi.org/10.3748/ wjg.v24.i36.4132

Yang M, Brackenbury WJ (2013) Membrane potential and cancer progression. Front. Physiol. 4:185. https://doi.org/10.3389/fphys.2013. 00185

Yang Z, Qin W, Chen Y, Yuan B, Song X, Wang B et al (2018) Cholesterol inhibits hepatocellular carcinoma invasion and metastasis by promoting CD44 localization in lipid rafts. Cancer Lett. 429: 66-77. https://doi.org/10.1016/j.canlet.2018.04.038

Yeagle, P. L. (2016). Biogenesis of Membrane Lipids. In The Membranes of Cells (pp. 57-71). Elsevier. https://doi.org/10.1016/b978-0-12800047-2.00003-6

Yen HY, Hoi KK, Liko I, Hedger G, Horrell MR, Song W et al (2018) PtdIns(4,5)P2 stabilizes active states of GPCRs and enhances selectivity of G-protein coupling. Nature 559(7714):423-427. https://doi. org/10.1038/s41586-018-0325-6

Yi M, Li J, Chen S, Cai J, Ban Y, Peng Q et al (2018) Emerging role of lipid metabolism alterations in Cancer stem cells. J. Exp. Clin. Cancer Res. BioMed Central Ltd. https://doi.org/10.1186/s13046018-0784-5

Young MM, Bui V, Chen C, Wang HG (2019) FTY720 induces noncanonical phosphatidylserine externalization and cell death in acute myeloid leukemia. Cell Death Dis. 10(11):1-14. https://doi.org/10. 1038/s41419-019-2080-5

Yu RK, Suzuki Y, Yanagisawa M (2010) Membrane glycolipids in stem cells. FEBS Lett. NIH Public Access. https://doi.org/10.1016/j. febslet.2009.08.026

Zalba, S., \& ten Hagen, T. L. M. (2017) Cell membrane modulation as adjuvant in cancer therapy. Cancer Treat. Rev. W.B. Saunders Ltd. https://doi.org/10.1016/j.ctrv.2016.10.008

Zech T, Ejsing CS, Gaus K, de Wet B, Shevchenko A, Simons K, Harder $\mathrm{T}$ (2009) Accumulation of raft lipids in T-cell plasma membrane domains engaged in TCR signalling. EMBO J. 28(5):466-476. https://doi.org/10.1038/emboj.2009.6

Zhao Z, Hao D, Wang L, Li J, Meng Y, Li P et al (2019) CtBP promotes metastasis of breast cancer through repressing cholesterol and activating TGF- $\beta$ signaling. Oncogene 38(12):2076-2091 https://doi. org/10.1038/s41388-018-0570-Z

Zheng K, Chen Z, Feng H, Chen Y, Zhang C, Yu J et al (2019) Sphingomyelin synthase 2 promotes an aggressive breast cancer phenotype by disrupting the homoeostasis of ceramide and sphingomyelin. Cell Death Dis. 10(3). https://doi.org/10.1038/s41419-019-1303-0

Zhu X, Jiang J, Shen H, Wang H, Zong H, Li Z et al (2005) Elevated $\beta 1$, 4-galactosyltransferase I in highly metastatic human lung cancer cells: Identification of E1 AF as important transcription activator. J. Biol. Chem. 280(13):12503-12516. https://doi.org/10.1074/jbc. M413631200

Zhuang L, Kim J, Adam RM, Solomon KR, Freeman MR (2005) Cholesterol targeting alters lipid raft composition and cell survival in prostate cancer cells and xenografts. J. Clin. Invest. 115(4):959968. https://doi.org/10.1172/JCI19935

Publisher's note Springer Nature remains neutral with regard to jurisdictional claims in published maps and institutional affiliations. 